Check for updates

Cite this: RSC Adv., 2018, 8, 22694

Received 27th April 2018

Accepted 2nd June 2018

DOI: $10.1039 / \mathrm{c} 8 \mathrm{ra03647 \textrm {k }}$

rsc.li/rsc-advances

\section{Arsenic removal from water/wastewater using layered double hydroxide derived adsorbents, a critical review}

\author{
Junya Wang, (D) ${ }^{a}$ Taiping Zhang, ${ }^{a}$ Min Li, ${ }^{a}$ Ying Yang, ${ }^{a}$ Peng Lu, ${ }^{b}$ Ping Ning*a \\ and Qiang Wang (iD ${ }^{\mathrm{c}}$
}

Arsenic pollution has become a worldwide environmental concern. Dangerous arsenic concentrations in natural waters threaten the health of millions of people, and this has received significant attention. Among the various technologies that have been developed for arsenic removal from water, the use of adsorption technology is considered to be a prevailing method, because the adsorption approach usually has high removal efficiency and the advantage of convenience of handling. In recent years, layered double hydroxides (LDHs) have become prime candidates for arsenic removal, due to their hydrophilic nature and cationic layered structures. Research on arsenic removal using LDHs is mainly focused on (1) the influence of the synthesis method and composition of the LDH, (2) the influence of the particle size of the LDH, (3) the influence of the Mg/Al ratio in LDHs, (4) LDH-based hybrids and (5) the competition with other anions. This paper provides a review of the currently available literature focusing on arsenic removal using LDHs for the five parts mentioned above. In addition, based on this overview, a closing section will suggest research efforts for future work. It is expected that this review will provide a summary of the main research in this area, and will also shed light on the direction of future development.
${ }^{a}$ Faculty of Environmental Science and Engineering, Kunming University of Science and Technology, Kunming, 650500, Yunnan, P. R. China. E-mail: 1456149879@qq.com; Tel: +8613708409187

${ }^{b}$ School of Materials Science and Chemical Engineering, Ningbo University, Ningbo, 315211, Zhejing, P. R. China

${ }^{c}$ College of Environmental Science and Engineering, Beijing Forestry University, 35 Qinghua East Road, Haidian District, Beijing 100083, P. R. China

\section{Introduction}

Arsenic (As), a metalloid which occurs naturally, is the $20^{\text {th }}$ most abundant element in the Earth's crust, the $14^{\text {th }}$ in seawater and the $12^{\text {th }}$ in the human body, and is a component of more than 245 minerals. ${ }^{1}$ These are mostly ores containing sulfide, along with copper, nickel, lead, cobalt, or other metals. As and its compounds are mobile in the environment. ${ }^{1}$ Most

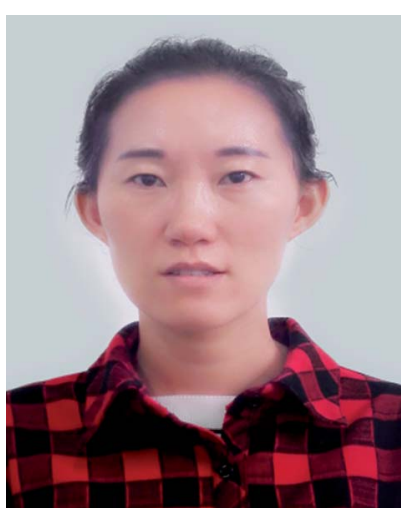

Junya Wang received her B.Sc from Heilongjiang University in 2007 and her M.Sc from the Guilin University of Technology in 2010. After that, she worked at the Guangxi Eco-engineering Vocational and Technical College. Following this, she attained her Ph.D from Beijing Forestry University in 2016. Since 2016, she has worked as an Associate Professor in the Faculty of Environmental Science and Engineering at Kunming University of Science and Technology in China. Her research interests are in environmental functional materials.

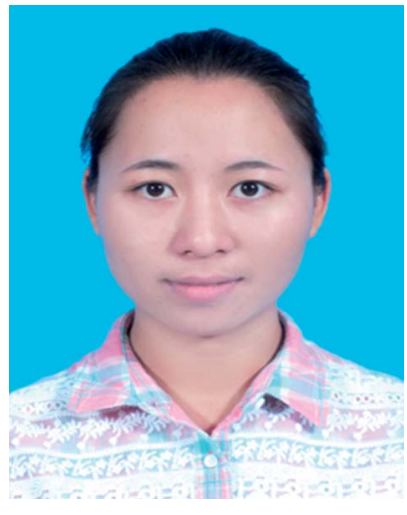

Taiping Zhang is a master's candidate at the College of Environmental Science and Engineering at Kunming University of Science and Technology in China. She received her bachelor's degree at Yuxi Normal University in June 2017. Her research interests are in adsorption materials. 
environmental As problems are the result of mobilization under natural conditions. However, mining activities, the combustion of fossil fuels, petroleum refining, sewage sludge, the use of As pesticides, herbicides, and crop desiccants, the ceramic manufacturing industries, and the use of As additives in livestock feed increase As concentrations in the environment. ${ }^{2-5}$ As occurs in the environment mainly as inorganic arsenic oxides, such as arsenite (As(III)), arsenate (As(v)) and methylated forms (e.g. $\left(\mathrm{CH}_{3}\right)_{3} \mathrm{As}$ and $\left.\left(\mathrm{CH}_{3}\right)_{2} \mathrm{AsOOH}\right) \cdot{ }^{6,7}$ As is a carcinogen for both humans and animals. ${ }^{89}$ Of the various sources of As in the environment, drinking water probably poses the greatest threat to human health. ${ }^{10}$ As is considered to be one of the most toxic pollutants, and is introduced into natural water in different ways. ${ }^{11}$ The World Health Organization (WHO) guideline value for As in drinking water was provisionally reduced in 1993 from 50 to $10 \mu \mathrm{g} \mathrm{L}^{-1}$. The new recommended value was chosen based on increasing awareness of the toxicity of As, particularly its carcinogenicity, and on the ability to measure it quantitatively. ${ }^{\mathbf{1 2}}$

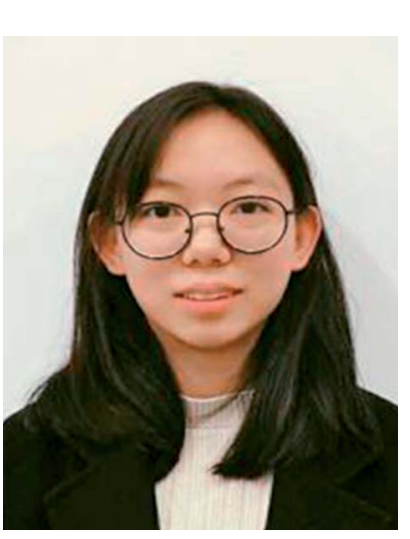

Min Li is currently a master's candidate in the Faulty of Environmental Science and Engineering at Kunming University of Science and Technology. She received her bachelor's degree at Hengyang Normal University in June 2017. Her research interest is the study of adsorbents.

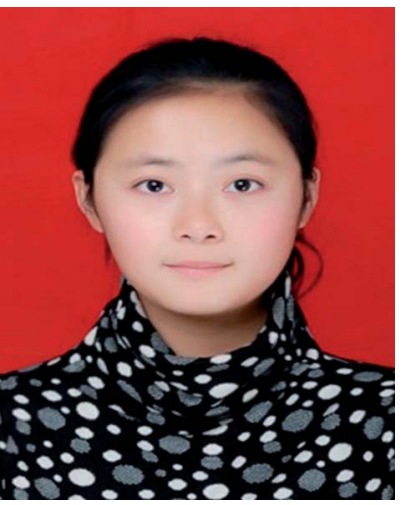

Ying Yang is currently a master's candidate in the Faulty of Environmental Science and Engineering at Kunming University of Science and Technology. She received her bachelor's degree at China West Normal University in 2016. Her research interests are in layered double hydroxide derived $\mathrm{CO}_{2}$ capture adsorbents.
Therefore, dangerous As concentrations in natural water have become one of the major worldwide environmental concerns. Millions of people have been exposed to high As concentrations (through contaminated drinking water), raising severe health problems, which have received significant attention. ${ }^{2,13,14}$ Up to now, different techniques have been developed and tried out for the removal of As from water (e.g. coagulation and flocculation, precipitation, membrane filtration, ion exchange and adsorption). ${ }^{15-21}$ Among these techniques, the removal of As from aqueous solutions using adsorption technology is the prevailing remediation method, because the adsorption approach usually has high removal efficiency and the advantage of convenience of handling. ${ }^{22-25}$ Several materials have already been proposed for the adsorption of As from water, which include biological materials, mineral oxides, activated carbons, polymer resins and LDHs etc. ${ }^{\mathbf{1 6 , 2 6 - 3 0}}$ Of these materials, LDHs have become the prime candidates for As removal, with As removal capacities in the range of $5-615 \mathrm{mg} \mathrm{g}^{-1}$, due to their hydrophilic nature and cationic layered structures. ${ }^{31-33}$ LDHs

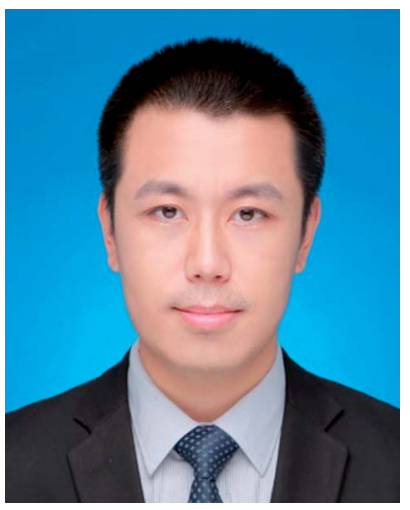

Peng $L u$ received his $B$.Sc. degree (2012) in Environmental Engineering from the North University of China and M.Sc. degree (2014) in hydraulic engineering from the University of Jinan, and his Ph.D. (2017) in Environmental Science and Engineering from Beijing Forestry University in China. Now he holds an Assistant Professor position in the School of Materials Science and Chemical Engineering at Ningbo University in China. His research is in the general area of membrane-based processes for gas/ liquid separation, and especially focuses on the preparation of layered double hydroxides (LDHs) as nanofiller modified thin-film composite (TFC) membranes.

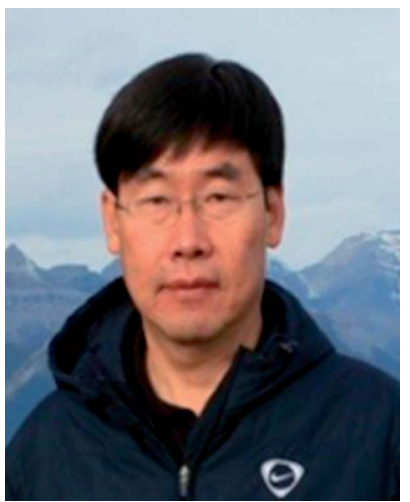

Ping Ning received his B.Sc. (1982) and M.Sc. (1985) from Kunming University of Science and Technology in China, and his Ph.D. (1995) from the University of Kaiserslautern in Germany. In 1995, he worked as a Postdoctoral Associate in the Department of Chemistry, University of Kaiserslautern. Since 1996, he has worked in the Faulty of Environmental Science and Engineering at Kunming University of Science and Technology. His research interest is environmental pollution control. He was given the award for nationally outstanding teachers and is a distinguished professor in the Yunnan province, and enjoys the State Council Special Allowance in China. 
are a class of ionic lamellar compound, and are made up of stacked positively charged brucite-like layers, with the interlayer spaces containing charge compensating anions and solvation molecules. ${ }^{34-37}$ Metal cations occupy the centers of octahedra whose vertexes contain hydroxide ions. The octahedra are connected through edge sharing to form an infinite sheet. ${ }^{38}$ The composition of LDHs is $\left[\mathrm{M}_{1-x}{ }^{2+} \mathrm{M}_{x}{ }^{3+}(\mathrm{OH})_{2}\right]\left[\mathrm{A}^{n-}\right]_{x / n} \cdot m \mathrm{H}_{2} \mathrm{O}$, as shown in Fig. 1 , where $\mathrm{M}^{2+}$ could be $\mathrm{Mg}^{2+}, \mathrm{Zn}^{2+}, \mathrm{Co}^{2+}, \mathrm{Ca}^{2+}$ or $\mathrm{Ni}^{2+}$ and $\mathrm{M}^{3+}$ could be $\mathrm{Al}^{3+}, \mathrm{Fe}^{3+}, \mathrm{Ga}^{3+}$ or $\mathrm{Mn}^{3+} \cdot \mathrm{A}^{n-}$ is the anion, which is intercalated in the interlayer for charge compensation, and it can an inorganic or an organic anion, e.g. $\mathrm{CO}_{3}{ }^{2-}, \mathrm{NO}_{3}{ }^{-}$, $\mathrm{Cl}^{-}$or $\mathrm{CH}_{3} \mathrm{COO}^{-}$etc. ${ }^{39-44}$ In addition, LDHs may also contain $\mathrm{M}^{+}$ and $\mathrm{M}^{4+}$ cations but these are limited to specific examples such as $\mathrm{Li}^{+}$and $\mathrm{Ti}^{4+} \cdot{ }^{34}$ Due to their well-defined layer structure with its interlayer distance of nanometers, large surface areas, high anion exchange capacities and $\mathrm{pH}$ buffering capacities, LDH materials have been intensively studied in a wide range of important areas ${ }^{45-50}$ e.g. catalysis, photochemistry, gas adsorption, flame retardants, electrochemistry, polymerization, magnetization, biomedical science and metal corrosion inhibition and for environmental applications. ${ }^{3451-62}$ Since LDHs often possess large surface areas, high anion exchange capacities, small crystallite sizes and good thermal stabilities and can also be easily recycled, they are excellent candidates for removing anions from aqueous solutions. ${ }^{63-65}$ LDHs remove As from water mainly via three mechanisms: (1) adsorption, (2) ion exchange, and (3) structure reconstruction. ${ }^{66,67}$ As can be removed by adsorption onto the external surface of LDHs. Also, the interlayer ions in LDHs can be replaced by As for the positively-charged binding sites in the hydroxide sheets. The latter mechanism is that As can be used as the interlayer ions to reconstruct the calcined LDHs and the LDHs can recover their original structure. The reaction equations for $\mathrm{As}(\mathrm{III})$ and $\mathrm{As}(\mathrm{v})$ with calcined LDHs are shown in eqn (1) and (2). A schematic illustration of the removal mechanism is shown in Fig. 2.

$$
\begin{aligned}
\mathrm{M}^{2+}+\mathrm{M}^{3+}+ & \mathrm{AsO}_{4}{ }^{3-} \rightarrow \\
& \mathrm{M}_{x}{ }^{2+} \mathrm{M}_{1-x}{ }^{3+}(\mathrm{OH})_{2 x+3 y-3 z}\left(\mathrm{As}^{3-}\right)_{z} \cdot m \mathrm{H}_{2} \mathrm{O}
\end{aligned}
$$

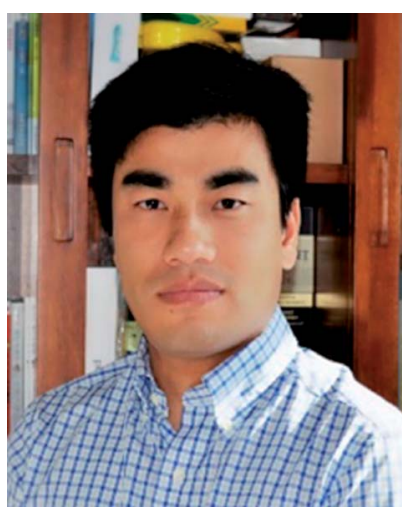

Qiang Wang received his B.Sc. (2003) and M.Sc. (2005) from the Harbin Institute of Technology in China, and his Ph.D. (2009) from POSTECH in South Korea. From 2009-2011, he worked as a Research Fellow in the Institute of Chemical and Engineering Sciences under A*STAR in Singapore. From 2011-2012, he worked as a Postdoctoral Associate in the Department of Chemistry, University of Oxford.

Since 2012, he has held a full professor position in the College of Environmental Science and Engineering at Beijing Forestry University researching environmental functional materials. He was awarded the China 1000 Talents Plan for Young Scholars in 2013. (a)
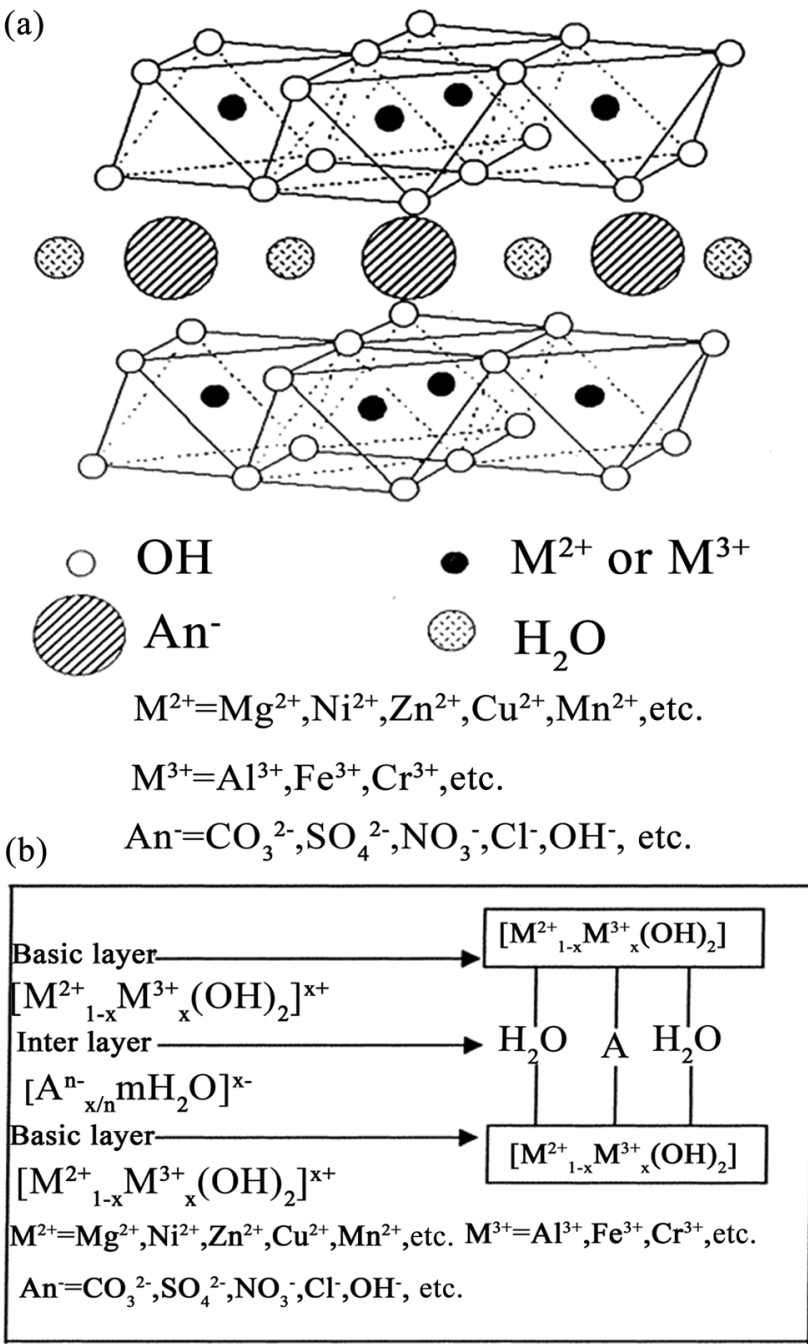

Fig. 1 Structure models for $\mathrm{LDHs}\left[\mathrm{M}_{1-x}{ }^{2+} \mathrm{M}_{x}{ }^{3+}(\mathrm{OH})_{2}\right]\left[\mathrm{A}^{n-}\right]_{x / n} \cdot m \mathrm{H}_{2} \mathrm{O}(\mathrm{a})$ $3 \mathrm{D}$ structure and (b) 2D structure (reproduced with permission from ref. 68)

$$
\begin{aligned}
\mathrm{M}^{2+}+\mathrm{M}^{3+}+ & \mathrm{AsO}_{2}{ }^{-} \rightarrow \\
& \mathrm{M}_{x}{ }^{2+} \mathrm{M}_{1-x}{ }^{3+}(\mathrm{OH})_{2 x+3 y-z}\left(\mathrm{As}^{-}\right)_{z} \cdot m \mathrm{H}_{2} \mathrm{O}
\end{aligned}
$$

Until now, research on LDHs for As removal has mainly focused on (1) the influence of the synthesis method and composition of the LDH, (2) the influence of the particle size of the LDH, (3) the influence of the $\mathrm{M}^{2+} / \mathrm{M}^{3+}$ ratio in LDHs, (4) LDH-based hybrids and (5) the competition with other anions, as well as the adsorption mechanism. Overall, the objective of this work is to review the currently available literature focusing on As removal using LDHs for the five parts mentioned above. Finally, based on this overview, a closing section will suggest research efforts for future work.

\section{Influence of the synthesis method and composition of the LDH}

Many methods have been employed to synthesize LDHs. Coprecipitation is a well-known method which is often used. ${ }^{68}$ 


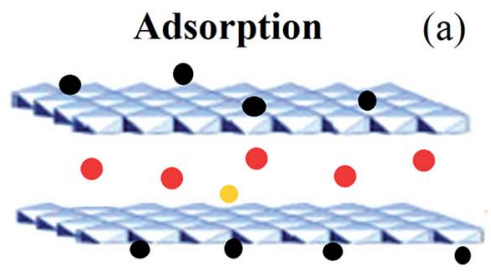

Ion exchange

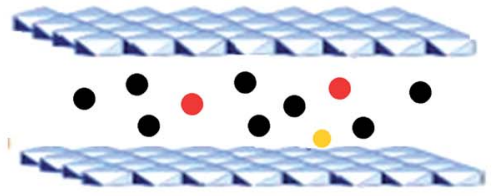

(b)

(c)

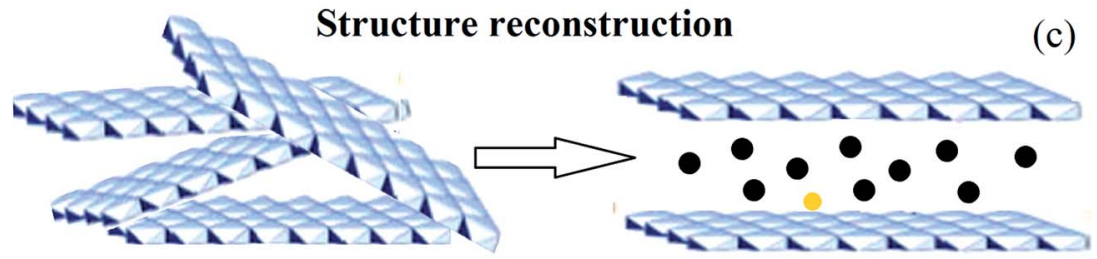

\section{Interlayer ions $\bullet$ As ions $\quad$ Water molecules}

Fig. 2 A schematic illustration of the As removal mechanism using a LDH.

Another well-known synthesis method is the hydrothermal method. ${ }^{69} \mathrm{~A}$ third method is urea hydrolysis, from which one can obtain LDHs after slow and homogenous precipitation of metal cations as a result of slow hydrolysis of urea at certain temperatures..$^{70}$ Moreover, the methods of ion exchange, structure reconstruction, sol-gel and microwave irradiation etc. are also used to synthesize LDHs. ${ }^{71-74}$ The use of different synthesis methods may influence the morphology of the LDH, thus influencing its adsorption capacity. ${ }^{70}$ Therefore, starting with conventional $\mathrm{Mg}-\mathrm{Al}-\mathrm{CO}_{3} \mathrm{LDHs}$, plenty of work has been done to study the influence of the synthesis method and composition of the LDH on As removal. You et al. ${ }^{75}$ used Mg-Al LDHs as adsorbents to remove $\mathrm{As}(\mathrm{III})$ from aqueous solutions for the first time. Uncalcined LDHs and calcined LDHs were compared in their study. It was found that As(III) could be adsorbed on both uncalcined and calcined chloride intercalation LDHs (Mg-Al-Cl LDH), but no adsorption occurred on carbonate intercalated LDHs ( $\left.\mathrm{Mg}-\mathrm{Al}-\mathrm{CO}_{3} \mathrm{LDH}\right)$. The adsorption isotherms of As(III) on a Mg-Al-Cl LDH showed typical L-type curves, which indicated that As(III) was strongly attracted to the LDH through ionexchange interactions. While on a calcined $\mathrm{Mg}-\mathrm{Al}-\mathrm{Cl} \mathrm{LDH}$, the As(III) adsorption isotherms were typical H-type curves, which suggested the high adsorption affinity of As(III), and As(III) was completely adsorbed at low concentrations. Nevertheless, no adsorption happened on the $\mathrm{Mg}-\mathrm{Al}-\mathrm{Cl} \mathrm{LDH}$, which indicated that $\mathrm{CO}_{3}{ }^{2-}$ was preferentially adsorbed, preventing $\mathrm{As}(\mathrm{III})$ exchange. However, after calcination at $450{ }^{\circ} \mathrm{C}$ for $2 \mathrm{~h}$, it was able to reach the highest As(III) adsorption capacity. However, what is the difference between a calcined LDH and an uncalcined one? The structure of the $\mathrm{Mg}-\mathrm{Al}-\mathrm{CO}_{3} \mathrm{LDH}$ will be changed during the calcination process. Upon thermal treatment, LDHs gradually lose their interlayer water, and then dehydroxylate and decarbonate to a large extent, leading to the formation of a mixed metal oxide with a poorly defined 3D network (see the left image in Fig. 2(c)). ${ }^{52}$ Moreover, calcined LDHs have relatively high surface areas, and exhibit memory effect. Because of their instability and memory effects, calcined LDHs can reconstruct their original layered structures upon adsorption of various anions (see Fig. 2(c)). ${ }^{34}$ Therefore, the highest $\mathrm{As}(\mathrm{III})$ adsorption capacity on the calcined $\mathrm{Mg}-\mathrm{Al}-\mathrm{CO}_{3}$ LDH may be explained by: (1) initial As(III) adsorption at the beginning of the calcined LDH reconstruction, (2) loss of $\mathrm{H}_{2} \mathrm{O}$ and $\mathrm{CO}_{3}{ }^{2-}$ (as $\mathrm{CO}_{2}$ ) resulting in higher calcined $\mathrm{LDH}$ anion exchange capacities, (3) fewer competing anions (e.g., $\mathrm{CO}_{3}{ }^{2-}$ ), as $\mathrm{CO}_{2}$ is lost during the As(III) adsorption process, and (4) higher surface areas as a result of calcination. Then, the influence of shaking time on As(III) adsorption using a calcined $\mathrm{Mg}-\mathrm{Al}-\mathrm{CO}_{3}$ LDH was also investigated, and it was shown that As(III) adsorption on the calcined $\mathrm{Mg}-\mathrm{Al}-\mathrm{CO}_{3} \mathrm{LDH}$ was a slow process and a quasiequilibrium was established after a $20 \mathrm{~h}$ reaction time. The results showed that over $80 \%$ of As(III) adsorption happened in the first $8 \mathrm{~h}$, and then the adsorption rate became slow from 8 to $28 \mathrm{~h}$. It was suggested that this two-step kinetic process might be related to the reconstruction mechanism of the calcined LDH. At the beginning of the adsorption process, reconstruction of calcined $\mathrm{LDH}$, release of $\mathrm{OH}^{-}$and adsorption of $\mathrm{CO}_{3}{ }^{2-}$ coincide. Therefore, the adsorption of As(III) during the reconstruction of the calcined $\mathrm{LDH}$ was a fast process and competition with $\mathrm{OH}^{-}$and $\mathrm{CO}_{3}{ }^{2-}$ was relatively low. However, after LDH reconstruction, As(III) adsorption became a competitive process with $\mathrm{OH}^{-}$and $\mathrm{CO}_{3}{ }^{2-}$, due to the increasing concentration of $\mathrm{OH}^{-}$and $\mathrm{CO}_{3}{ }^{2-}$ in the solution, which led to a slow adsorption process. The results from investigating the influence of $\mathrm{pH}$ on As(III) adsorption showed that the LDHs had high $\mathrm{pH}$ buffering capacities, while for calcined LDHs, As(III) adsorption was a function of $\mathrm{pH}$.

Following this, Yang et al. ${ }^{76}$ carried out a systematic investigation of removal of $\mathrm{As}(\mathrm{v})$ using calcined and uncalcined $\mathrm{Mg}$ $\mathrm{Al}-\mathrm{CO}_{3} \mathrm{LDHs}$ from dilute aqueous solutions representing "too clean to clean" model power-plant effluent streams, whose contaminant levels are expected to be at trace ppb levels. The results indicated that both calcined and uncalcined $\mathrm{Mg}-\mathrm{Al}-\mathrm{CO}_{3}$ 
LDHs exhibited better adsorption performance on As(v), and the adsorption isotherms obeyed the Freundlich model. Similarly, the calcined $\mathrm{Mg}-\mathrm{Al}-\mathrm{CO}_{3} \mathrm{LDH}$ displayed a higher As(v) adsorption capacity than the uncalcined one. In addition, the influence of $\mathrm{pH}$ on $\mathrm{As}(\mathrm{v})$ adsorption on uncalcined and calcined $\mathrm{Mg}$ $\mathrm{Al}-\mathrm{CO}_{3} \mathrm{LDHs}$ was also tested. Results showed that the starting solution $\mathrm{pH}$ did not obviously affect the adsorption of $\mathrm{As}(\mathrm{v})$ on the calcined LDH, as long as it was higher than 4; however, for the uncalcined $\mathrm{LDH}$, the initial $\mathrm{pH}$ had a significant influence on the adsorption capacity for As(v). This is because the point of zero charge $\left(\mathrm{pH}_{\mathrm{pzc}}\right)$ for the uncalcined $\mathrm{LDH}$ was normally in the range 6.8-8.9, and the surface of the $\mathrm{LDH}$ is negatively charged when $\mathrm{pH}>\mathrm{pH}_{\mathrm{pzc}}$. Therefore, the $\mathrm{As}(\mathrm{v})$ anionic species will be repelled by the $\mathrm{LDH}$ surface in a higher $\mathrm{pH}$ range. However, for $\mathrm{pH}<\mathrm{pH}_{\mathrm{pzc}}$, the $\mathrm{LDH}$ surface is positively charged, which usually favors the uptake of negatively charged anionic species. On the other hand, as reported, a very low $\mathrm{pH}$ can negatively influence the stability of the LDH structure and therefore leads to a decrease in the adsorption capacity for As anions. At a higher $\mathrm{pH}$ range, the negative effect of the $\mathrm{pH}$ may be further compounded by the increasing competitive effect of $\mathrm{OH}^{-}$adsorption on the LDH. Moreover, the impact of the As oxidation state on the adsorption performance on LDHs was also investigated. The results revealed that $\mathrm{As}(\mathrm{v})$ is more easily adsorbed on both the calcined and uncalcined LDHs than As(III). In addition, Chetia et al. ${ }^{77}$ studied the removal of As from contaminated water using calcined $\mathrm{Mg}-\mathrm{Al}-\mathrm{CO}_{3} \mathrm{LDHs}$ as the adsorbents. Results showed that $100 \mathrm{mg}$ of the $\mathrm{Mg}-\mathrm{Al}-\mathrm{CO}_{3} \mathrm{LDH}$ can remove As to the extent of $99.99 \%$ from $0.1 \mathrm{ppm}$ As solution under the conditions of adsorption for $90 \mathrm{~min}$ at $200 \mathrm{rpm}$ and a $\mathrm{pH}$ of 7.5. In addition, the experiment showed that the adsorption process could be described by the Freundlich model.

Moreover, Liu et $a .^{78}$ studied As(v) adsorption on lithium/ aluminum LDHs intercalated by chloride ( $\mathrm{Li}-\mathrm{Al}-\mathrm{Cl} \mathrm{LDH})$. In order to investigate the reaction of $\mathrm{As}(\mathrm{v})$ on the $\mathrm{Li}-\mathrm{Al}-\mathrm{Cl} \mathrm{LDH}$ and gibbsite, adsorption isotherms, envelopes (see Fig. 3) and the extended X-ray absorption fine structure (EXAFS) technique were employed in this paper. The results showed that the Li-Al$\mathrm{Cl}$ LDH displayed a superior adsorption capacity on As(v) over gibbsite. Although the surface area of gibbsite was larger than that of the $\mathrm{Li}-\mathrm{Al}-\mathrm{Cl} \mathrm{LDH}$, the maximum adsorption value of As(v) on the Li-Al-Cl LDH was $24.19 \mathrm{mg} \mathrm{g}^{-1}$, which was approximately six times higher than that of gibbsite $(3.86 \mathrm{mg}$ $\mathrm{g}^{-1}$ ) as shown in Fig. 3(a). This is because the surfaces of gibbsite do not take part in ligand exchange reactions, since the $\mathrm{OH}^{-}$groups on the planar surfaces of gibbsite are completely charge-satisfied and relatively inert. Therefore, the only active sites for adsorption reactions are the $\mathrm{pH}$-dependent edges that have an abundance of under coordinated $\mathrm{O}$ atoms which can never be fully charge-satisfied by the addition or removal of a proton. Meanwhile the adsorption envelopes of $\mathrm{As}(\mathrm{v})$ on the $\mathrm{Li}-\mathrm{Al}-\mathrm{Cl} \mathrm{LDH}$ were very sensitive to the $\mathrm{pH}$ when the $\mathrm{pH}$ was between 4.0 and 7.0 (see Fig. 3(b)). However, it displayed insensitivity to the $\mathrm{pH}$ when the $\mathrm{pH}$ was above 7.0 , which is approaching the $\mathrm{pH}_{\mathrm{pzc}}$ of the Li-Al-Cl LDH (7.22). Therefore, from comparing with gibbsite, it was suggested that the superior adsorption capacity of the $\mathrm{Li}-\mathrm{Al}-\mathrm{Cl} \mathrm{LDH}$ was mainly
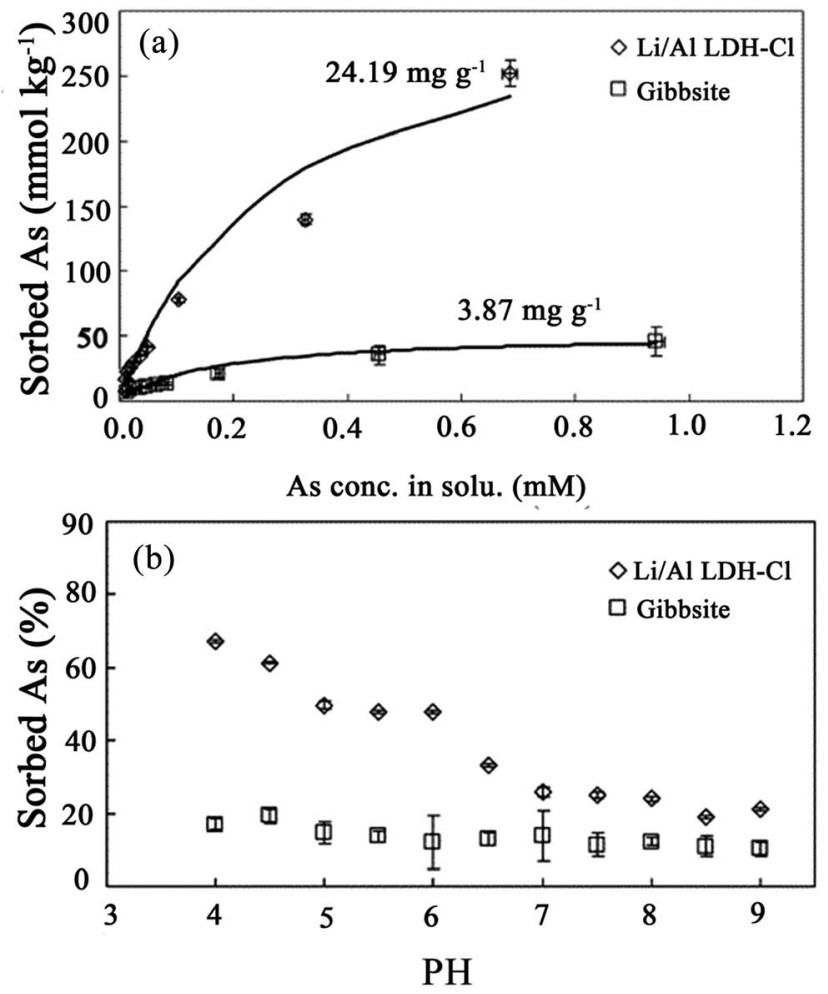

Fig. 3 (a) Adsorption isotherms for arsenate reacted with the $\mathrm{Li}-\mathrm{Al}-\mathrm{Cl}$ $\mathrm{LDH}$ and with gibbsite at a $\mathrm{pH}=5.0$, (b) adsorption envelopes for arsenate reacted with the $\mathrm{Li}-\mathrm{Al}-\mathrm{Cl} \mathrm{LDH}$ and with gibbsite (adapted with permission from ref. 78).

because of the two different adsorption sites in the structure. It was found that treatment with $\mathrm{LiCl}$ can lead to the intercalation of $\mathrm{Li}$ cations into the host structure of $\mathrm{Al}(\mathrm{OH})_{3}$ to form the $\mathrm{Li}-\mathrm{Al}-\mathrm{Cl} \mathrm{LDH}$. The $\mathrm{Li}$ cations occupied the vacant octahedral holes within $\mathrm{Al}(\mathrm{OH})_{3}$ and transformed the surface of the $\mathrm{Al}(\mathrm{OH})_{3}$ layers into active adsorption sites with a high affinity for $\mathrm{As}(\mathrm{v})$, as a result of the additional positive charge brought by the $\mathrm{Li}$ cations and the raising of the $\mathrm{pH}_{\mathrm{pzc}}$ of the $\mathrm{Li}-$ $\mathrm{Al}-\mathrm{Cl} \mathrm{LDH}$. Then, Liu et al. ${ }^{79}$ also incorporated both molecular spectroscopic and macroscopic studies to determine the adsorption behavior of $\mathrm{As}(\mathrm{v})$ on the $\mathrm{Li}-\mathrm{Al}-\mathrm{Cl} \mathrm{LDH}$, which not only contained the beginning transfer process but also contained the subsequent adsorption mechanisms. The results proved that inner-sphere complexes were the main $\mathrm{As}(\mathrm{v})$ adsorption configurations on the planar surfaces and edges of the Li-Al-Cl LDH. From the results of the kinetics study, As(v) adsorption on the $\mathrm{Li}-\mathrm{Al}-\mathrm{Cl} \mathrm{LDH}$ can also be separated into two processes. One is the fast reaction process; the other is the slow reaction process. This biphasic As(v) adsorption behavior is partially attributable to: (i) there being two different adsorption sites associated with Li, exposed planar surfaces, and $\mathrm{Al}$, which exists on the edges of the double hydroxyl layers, and (ii) micropore adsorption sites within the Li-Al-Cl LDH surfaces. From the results on the activation energies derived by the Arrhenius equation, it was indicated that the diffusion process was a step involving $\operatorname{As}(\mathrm{v})$ adsorption restriction on the Li-Al-Cl LDH. 
Furthermore, Grover et $a .^{\mathbf{8 0 , 8 1}}$ did a systematic study on the influence of the synthesis method and composition of the LDH on the As adsorption performance. Two types of LDH, hydrotalcite and hydrocalumite, with different compositions of layers and interlayers, were used in their study to remove As(III) from the solutions. Based on the kinetics study, the results showed that the anion exchange process was very fast and apparently attained a steady state between 8 and $16 \mathrm{~h}$. The synthesis method had an impact on the adsorption capacity of As on the LDHs. The LDH synthesized using the coprecipitation method displayed a higher adsorption capacity than that synthesized using the hydrothermal method. One reason is that the LDHs synthesized using the hydrothermal method had large crystal sizes leading to small surface areas. The other is that LDHs synthesized using the hydrothermal method were more crystalline in comparison with those synthesized using the coprecipitation method and it is harder to break the bonds between the layers in the former than in the latter. The results from XRD showed that the $d_{003}$ spacing is unchanged after exchange in the hydrothermally synthesized $\mathrm{LDH}$ because the exchange was mainly on the surfaces and edges. What's more, the type of interlayer anion in the $\mathrm{LDH}$ had a significant influence on the As uptake capacity of the LDH. Therefore, hydrotalcite and hydrocalumite with the same charge density and different interlayer anions displayed different As uptake capacities. The As(III) uptake capacities for the hydrotalcites were in the following order: $\mathrm{Mg}-\mathrm{Al}-\mathrm{NO}_{3}>\mathrm{Mg}-\mathrm{Al}-\mathrm{Cl}>\mathrm{Mg}-\mathrm{Al}-\mathrm{CO}_{3}$. For the hydrocalumites, the As(III) uptake capacity order was $\mathrm{Ca}-\mathrm{Al}-\mathrm{NO}_{3}$ $>\mathrm{Ca}-\mathrm{Al}-\mathrm{Cl}$. This was because the $d_{003}$ spacing reflected that nitrate has a larger size than chloride. Therefore, the nitrate resulted in larger interlayer spacing, which facilitated As(III) exchange. Finally, it was thought that the As(III) adsorption mechanism in the hydrocalumite-type LDH seemed to be topotactic exchange, and then dissolution and reprecipitation. Guo et $a{ }^{82}$ also used hydrocalumite as an adsorbent to treat $\operatorname{As}(\mathrm{v})$ solutions with a wide range of initial concentrations. The results showed that the maximum uptake capacity of hydrocalumite for As(v) was $361.7 \mathrm{mg} \mathrm{g}^{-1}$. To study the adsorption mechanism, it was found that the process of dearsenication in the solution using hydrocalumite was principally driven by its dissolution and the subsequent precipitation of johnbaumite and other arsenic-bearing minerals (probably sainfeldite or bulachite) in the solid-solution series.

In addition, Guo et al. $^{83}$ developed a novel LDH, which contains lanthanum $\left(\mathrm{La}^{3+}\right)$ in it $(\mathrm{Cu}-\mathrm{Mg}-\mathrm{Fe}-\mathrm{La} \mathrm{LDH})$ for $\mathrm{As}(\mathrm{v})$ removal in aqueous solution. The purpose of the introduction of $\mathrm{La}^{3+}$ into the $\mathrm{LDH}$ was to try to improve the adsorption capacity of $\mathrm{As}(\mathrm{v})$ and broaden the application field of $\mathrm{LDH}$ functional materials. The results showed that the $\mathrm{Cu}-\mathrm{Mg}-\mathrm{Fe}-\mathrm{La}$ LDHs displayed highly efficient As(v) adsorption capacities from aqueous solutions. When the initial $\mathrm{As}(\mathrm{v})$ concentration was $5 \mathrm{mg} \mathrm{L}{ }^{-1}$ with an adsorbent dosage of $1.5 \mathrm{~g} \mathrm{~L}^{-1}$, the final As(v) concentration was lower than $10 \mu \mathrm{L}^{-1}$ after adsorption. Moreover, with increasing $\mathrm{La}^{3+}$ content in the $\mathrm{LDH}$, the $\mathrm{As}(\mathrm{v})$ adsorption capacity of the LDH increased. The adsorption efficiency of this $\mathrm{La}^{3+}$ containing $\mathrm{LDH}$ was dependent on the initial $\mathrm{pH}$ of the solution, and the co-existing ions had different negative effects on the $\mathrm{As}(\mathrm{v})$ adsorption performance. The main mechanism controlling the adsorption of As(v) onto the LDHs might also be ion exchange with carbonate and ligand exchange with the layer $\mathrm{OH}$ group. It was proposed that their high $\mathrm{As}(\mathrm{v})$ removal efficiencies would make $\mathrm{Cu}-\mathrm{Mg}-\mathrm{Fe}-\mathrm{La} \mathrm{LDHs}$ potential adsorbents for the treatment of water contaminated with As.

In addition to changing the divalent $\mathrm{Mg}$, the trivalent $\mathrm{Al}$ has also been substituted by other cations in LDHs. Otgonjargal et $a .^{66}$ prepared a $\mathrm{Mn}-\mathrm{Fe}-\mathrm{CO}_{3} \mathrm{LDH}$ using the co-precipitation method to remove $\mathrm{As}(\mathrm{III})$ and $\mathrm{As}(\mathrm{v})$ from aqueous solutions. The adsorption capacities of the $\mathrm{Mn}-\mathrm{Fe}-\mathrm{CO}_{3} \mathrm{LDH}$ for $\mathrm{As}(\mathrm{III})$ and $\operatorname{As}(\mathrm{v})$ were 0.02 and $0.009 \mathrm{mg} \mathrm{g}^{-1}$, respectively, which were higher than those of the iron- and manganese-containing compounds such as the Fe- and Mn-enriched samples (an adsorption capacity of $14 \mathrm{mg} \mathrm{g}^{-1}$ at an effluent concentration of $\left.50 \mu \mathrm{g} \mathrm{L}{ }^{-1}\right) .{ }^{84}$ Subsequently, Bagherifam et al. ${ }^{85}$ carried out a study on $\mathrm{As}(\mathrm{III})$ and $\mathrm{As}(\mathrm{v})$ removal from a simulated soil solution using $\mathrm{Zn}-\mathrm{Al}-\mathrm{SO}_{4} \mathrm{LDHs}$ as adsorbents. The results revealed that the maximum uptake values of the $\mathrm{Zn}-\mathrm{Al}-\mathrm{SO}_{4} \mathrm{LDHs}$ on As(III) and As(v) were 34.24 and $47.39 \mathrm{mg} \mathrm{g}^{-1}$, respectively. The adsorption kinetics of As(v) followed pseudo-second order while those of As(III) uptake showed better correlation with the intraparticle diffusion model. Moreover, the $\mathrm{Zn}-\mathrm{Al}-\mathrm{SO}_{4} \mathrm{LDH}$ displayed higher selectivity for As(v) compared to that with As(III).

Furthermore, Lu et al. ${ }^{86}$ used Zn-Fe LDHs in both simulated and practical polluted water to achieve removal of As(v). In the single pollution system, the results showed that the maximum adsorption capacity for As(v) was $151.37 \mathrm{mg} \mathrm{g}^{-1}$. In the batch experiments, the residual concentration of $\mathrm{As}(\mathrm{v})$ could be decreased from $2 \mathrm{mg} \mathrm{L}^{-1}$ to lower than $0.005 \mathrm{mg} \mathrm{L}^{-1}$, when the adsorbent dosage was $0.2 \mathrm{~g} \mathrm{~L}^{-1}$. However, in the practical polluted water, after adsorption, the results showed that both the As residual concentrations could be made to meet the limit value for drinking water standards recommended by WHO with a dosage of $\mathrm{Zn}-\mathrm{Fe} \mathrm{LDH}$ of $0.2 \mathrm{~g} \mathrm{~L}^{-1}$. Subsequently, Huang et al. ${ }^{87}$ synthesized $\mathrm{Mg}-\mathrm{Al} \mathrm{LDHs}$ with $\mathrm{Cl}^{-}$and $\mathrm{CO}_{3}{ }^{2-}$ as the interlayer anions via a solvothermal method to remove $\mathrm{As}(\mathrm{v})$ and $\mathrm{F}^{-}$in water. The maximum uptake capacities of the $\mathrm{Mg}-\mathrm{Al} \mathrm{LDHs}$ for $\operatorname{As}(\mathrm{v})$ and $\mathrm{F}^{-}$were 125.8 and $28.6 \mathrm{mg} \mathrm{g}^{-1}$, respectively, under neutral conditions. In order to investigate the detailed adsorption mechanisms for As(v) and $\mathrm{F}^{-}, \mathrm{As}(\mathrm{v})$ and $\mathrm{F}^{-}$saturated $\mathrm{Mg}-\mathrm{Al}$ LDHs were prepared. XPS and XRD were used to characterize the LDHs before and after the adsorption of As(v) and $\mathrm{F}^{-}$(see Fig. 4). As shown in Fig. 4(a), after adsorption, an As signal appeared and the peak for $\mathrm{Cl} 2 \mathrm{p}$ at $198 \mathrm{eV}$ disappeared, which all indicated that the As(v) ions had been successfully adsorbed on the $\mathrm{Mg}-\mathrm{Al} \mathrm{LDHs}$ with an exchange with $\mathrm{Cl}^{-}$. Besides, the high resolution Cls spectra of the LDHs before and after As(v) adsorption (see inset in the Fig. 4(a)) revealed that the intensity of the carbonate located at $288.4 \mathrm{eV}$, which could be assigned to the intercalated $\mathrm{CO}_{3}{ }^{2-}$ of the $\mathrm{Mg}-\mathrm{Al}$ LDHs, decreases significantly after As(v) adsorption, indicating that the partial replacement of the interlayer $\mathrm{CO}_{3}{ }^{2-}$ had also exchanged with As(v). For $\mathrm{F}^{-}$adsorption, in Fig. 4(b), the peaks at $198 \mathrm{eV}(\mathrm{Cl} 2 \mathrm{p})$ and $267 \mathrm{eV}$ (Cl 2s), which show that the fluoride had disappeared after $\mathrm{F}^{-}$adsorption, indicate that there had been ion 

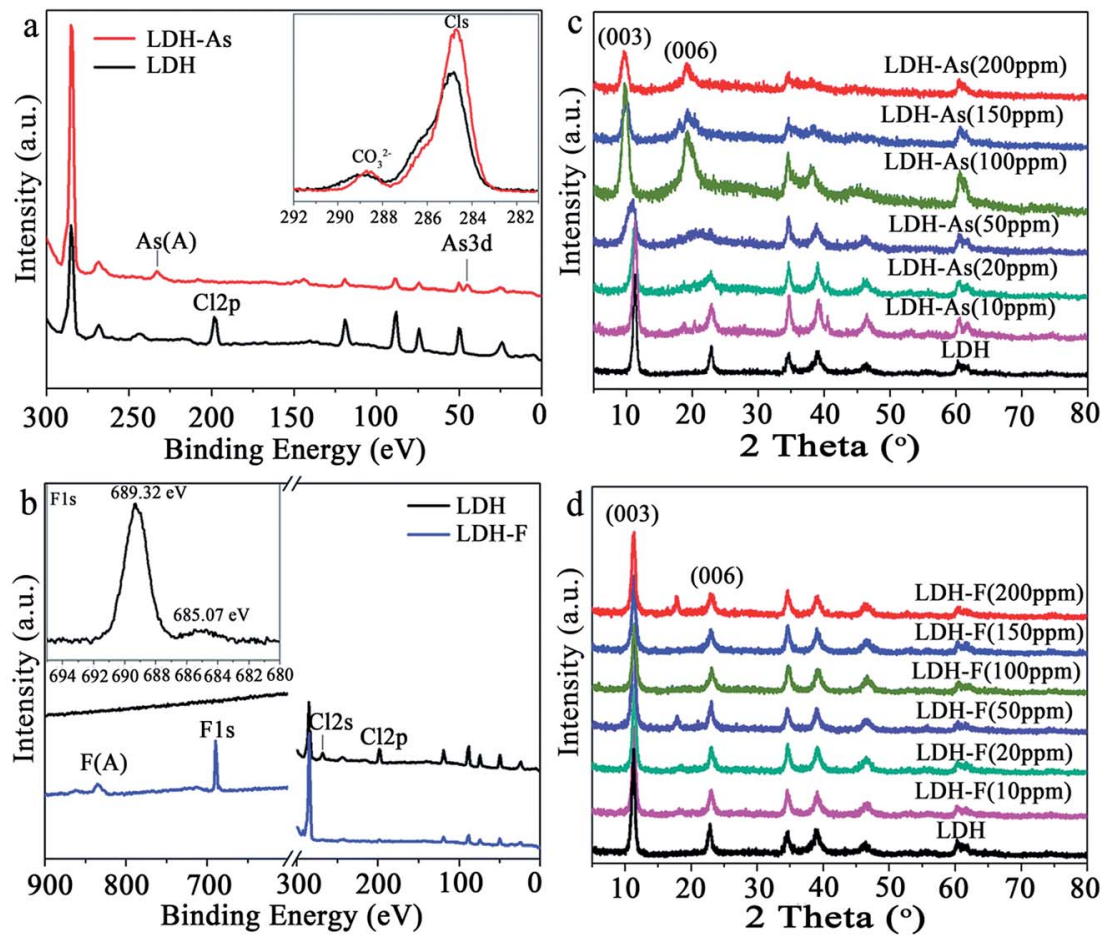

Fig. 4 XPS spectra of the Mg-Al LDHs before and after the adsorption of (a) $A s(v)$ and (b) $F^{-}$; XRD patterns of the Mg-Al-LDHs after the adsorption of (c) As(v) and (d) $\mathrm{F}^{-}$with different initial concentrations (adapted with permission from ref. 87).

exchange between $\mathrm{Cl}^{-}$and $\mathrm{F}^{-}$. The high resolution $\mathrm{F}$ 1s spectrum is shown in the inset of Fig. 4(b). The small peak at $685 \mathrm{eV}$ and the main peak at $689.3 \mathrm{eV}$ can be assigned to the physically adsorbed $\mathrm{F}^{-}$on the surface and the $\mathrm{F}^{-}$in the lattice of the $\mathrm{Mg}^{-}$ Al LDHs, respectively. These results suggested that $\mathrm{F}^{-}$had mainly intercalated into the layers rather than adsorbing on the surface. In addition, there was no obvious change in the Cls spectra observed for the Mg-Al LDHs before and after $\mathrm{F}^{-}$ adsorption, which indicated that $\mathrm{CO}_{3}{ }^{2-}$ may not have taken part in ion exchange during the $\mathrm{F}^{-}$adsorption process. Fig. 4(c) shows the XRD patterns of Mg-Al LDHs after the adsorption of $\operatorname{As}(v)$. It can be see that there was no obvious change in the interlayer spacing of the $\mathrm{Mg}-\mathrm{Al} \mathrm{LDHs}$ detected at low concentrations. However, at high concentrations, there was an obvious shift observed in the interlayer spacing to a higher diffraction angle, which indicated that $\mathrm{As}(\mathrm{v})$ had intercalated into the

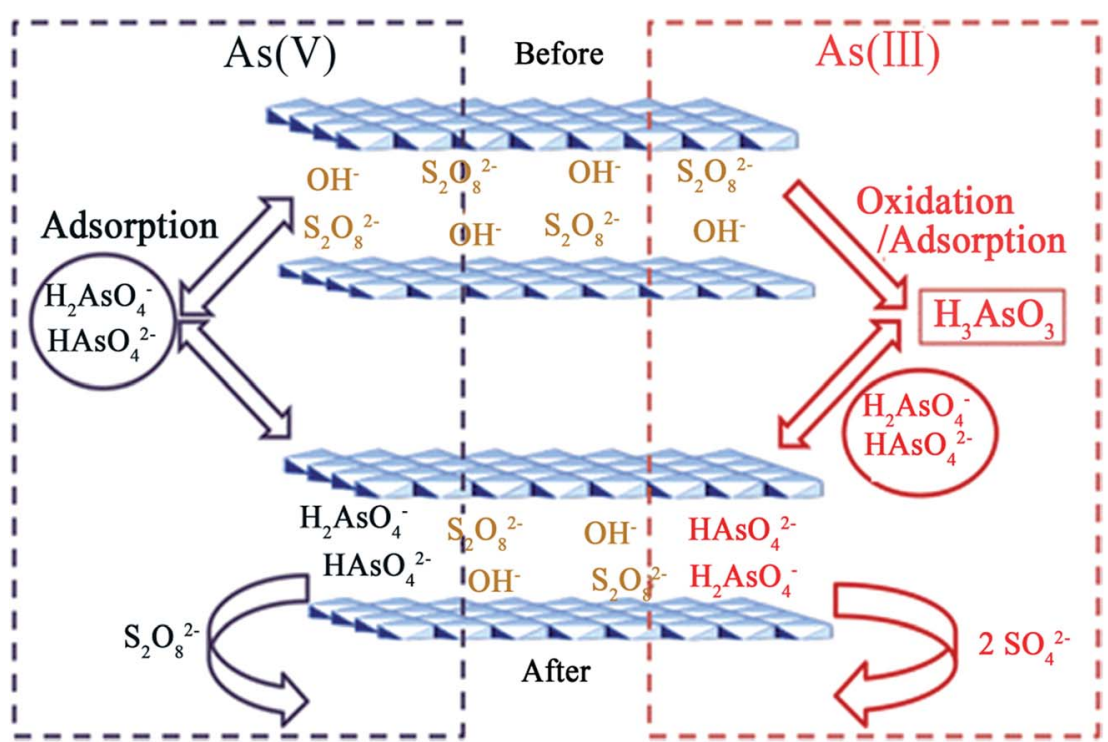

Fig. 5 A schematic diagram of the proposed mechanism for $\mathrm{As}(\mathrm{III})$ and $\mathrm{As}(\mathrm{V})$ adsorption on the $\mathrm{Mg}-\mathrm{Fe}-\mathrm{S}_{2} \mathrm{O}_{8} \mathrm{LDH}$ (reproduced with permission from ref. 88). 
interlayer and expanded the interlayer. Meanwhile for $\mathrm{F}^{-}$ adsorption (see Fig. 4(d)), nearly no change could be seen with a full range of concentrations. The reason was that the only $\mathrm{Cl}^{-}$ exchanged with $\mathrm{F}^{-}$and they are nearly the same size. Based on the above results, it can be concluded that the main adsorption mechanism between the interlayer anions in the $\mathrm{Mg}-\mathrm{Al} \mathrm{LDHs}$ and $\mathrm{As}(\mathrm{v})$ and $\mathrm{F}^{-}$in the solution was also that of ion exchange.

Recently, Lu et al. ${ }^{88}$ combined ferric-based LDHs (Mg-Fe$\mathrm{S}_{2} \mathrm{O}_{8} \mathrm{LDH}$ ) with oxidant anion (persulfate) intercalation using a calcination-reconstruction method. Since the exchangeable persulfate ions in the LDH had strong oxidation abilities, the experimental results showed that the As(III) species in water were almost completely oxidized to the $\mathrm{As}(\mathrm{v})$ state and had adsorbed onto the $\mathrm{Mg}-\mathrm{Fe}-\mathrm{S}_{2} \mathrm{O}_{8} \mathrm{LDH}$ simultaneously. For As(III) and $\mathrm{As}(\mathrm{v})$ in a single-pollutant system, each maximum uptake capacity was able to reach 75.00 and $75.63 \mathrm{mg} \mathrm{g}^{-1}$, respectively. Moreover, in the batch experiment, for the removal of both As(III) and As(v) together in the pollutant system, when the adsorbent dosage was $0.5 \mathrm{~g} \mathrm{~L}^{-1}$, the residual arsenic concentration in the solution could be reduced from $1 \mathrm{mg} \mathrm{\textrm {L } ^ { - 1 }}$ to lower

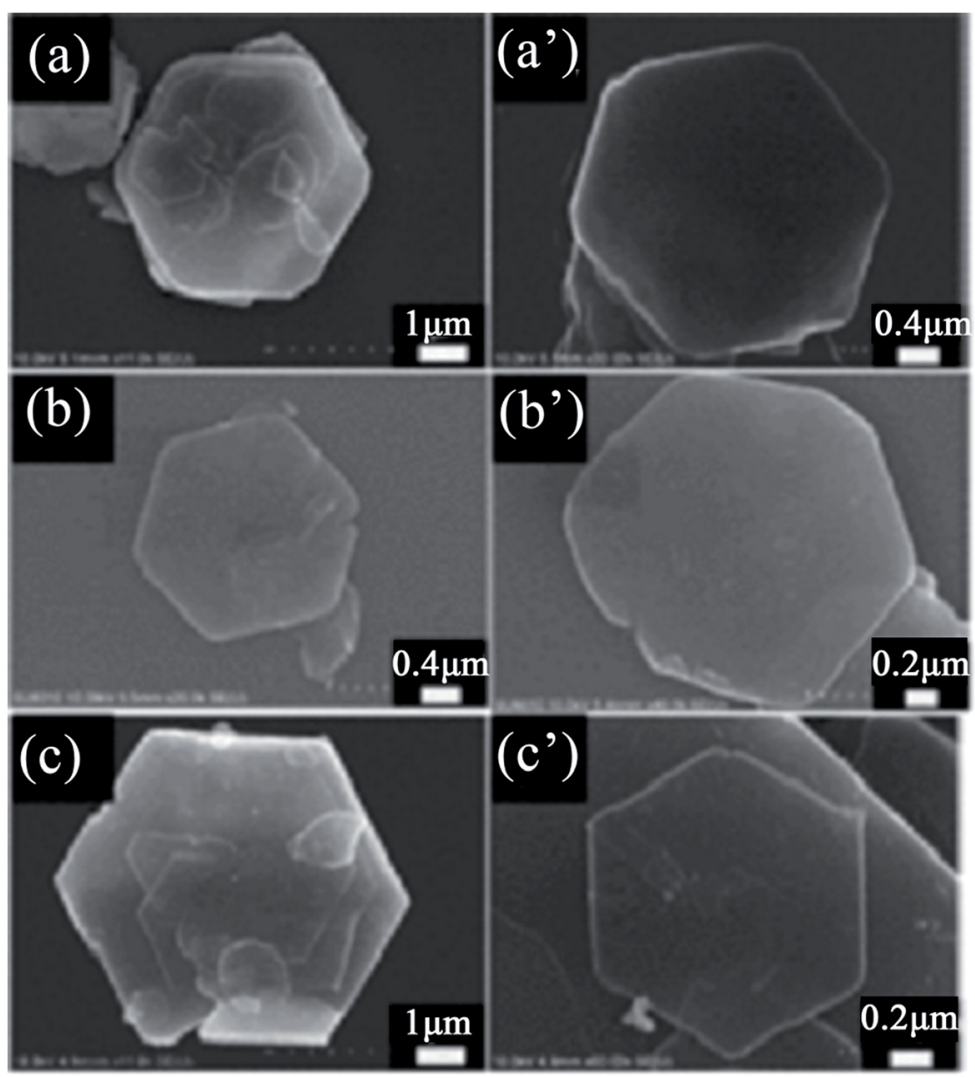

(d)

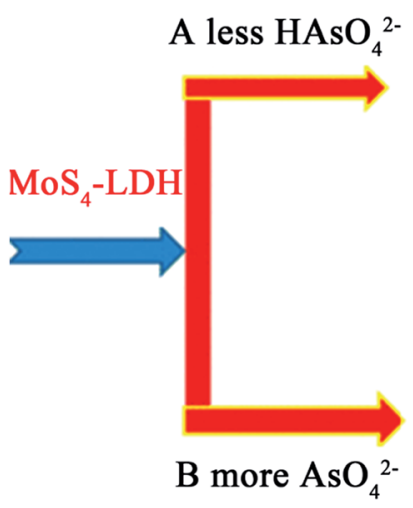

LDH layer
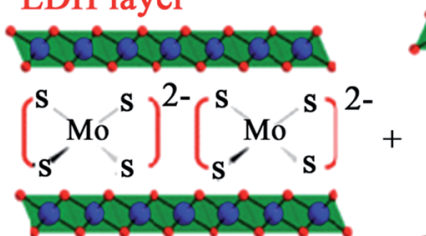

more $\mathrm{d}=1.07 \mathrm{~nm}$
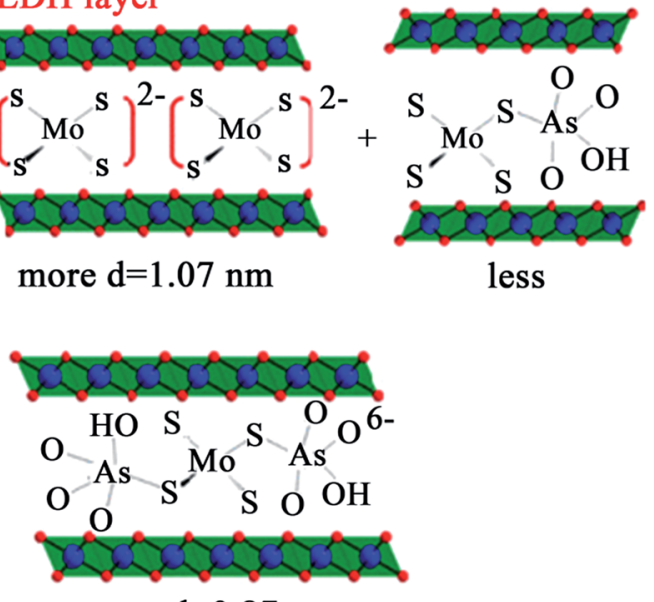

more $\mathrm{d}=0.87 \mathrm{~nm}$

Fig. 6 SEM images of the samples after $M_{0} S_{4}-L D H$ adsorption with (a and $\left.a^{\prime}\right) 10$ ppm As(III), (b and b') 300 ppm As(II) and (c and c') 10 ppm As(v); (d) a scheme showing the dominant phases and possible binding modes of $\mathrm{MoS}_{4}{ }^{2-}$ with $\mathrm{HAsO}_{4}{ }^{2-}$ in the LDH gallery (adapted with permission from ref. 89). 
than the limit value for drinking water standards recommended by WHO. The main removal mechanism of $\mathrm{As}(\mathrm{III})$ and $\mathrm{As}(\mathrm{V})$ using the $\mathrm{Mg}-\mathrm{Fe}-\mathrm{S}_{2} \mathrm{O}_{8} \mathrm{LDH}$ was speculated on, and includes two approaches: one is the in situ oxidation of $\mathrm{As}(\mathrm{III})$ to $\mathrm{As}(\mathrm{v})$ by persulfate and the other is the exchange of $\mathrm{S}_{2} \mathrm{O}_{8}{ }^{2-}$ with $\mathrm{As}(\mathrm{v})$. Fig. 5 displays a schematic diagram of the proposed removal mechanism. The overall reaction with respect to the persulfate anion is as follows:

$$
\mathrm{As}(\mathrm{III})+\mathrm{S}_{2} \mathrm{O}_{8}{ }^{2-} \rightarrow \mathrm{As}(\mathrm{v})+2 \mathrm{SO}_{4}{ }^{2-}
$$

Very recently, Ma et al. ${ }^{89}$ synthesized an $\mathrm{Mg} / \mathrm{Al} \mathrm{LDH}$ intercalated with $\mathrm{MoS}_{4}{ }^{2-}$ for capturing the oxoanions of $\mathrm{As}(\mathrm{III}) / \mathrm{As}(\mathrm{v})$ $\left(\mathrm{HAsO}_{3}{ }^{2-} / \mathrm{HAsO}_{4}{ }^{2-}\right)$. This $\mathrm{MoS}_{4}-\mathrm{LDH}$ exhibited very high removal rates for As(III) and As(v) of up to $99 \%$ and the maximum uptake capacities for As(III) and As(v) were 99 and $56 \mathrm{mg} \mathrm{g}^{-1}$, respectively. From the SEM images (see Fig. 6), it can be seen that the crystallites of the LDHs fully maintained their hexagonal prismatic shape after the adsorption of As(III) and As(v), which proved that topotactic insertion of the adsorbed anionic complexes during the uptake process had taken place. Therefore, the dominant phases and possible binding modes of $\mathrm{MoS}_{4}{ }^{2-}$ with $\mathrm{HAsO}_{4}{ }^{2-}$ in the $\mathrm{LDH}$ gallery were speculated on, as shown in Fig. 6(d). When the anion was at low concentrations, the adsorbed amount was not large enough to produce a new discernable phase; thus, the $1.07 \mathrm{~nm} d_{\text {basal }}$ was mainly $\mathrm{MoS}_{4^{-}}$ LDH (see Fig. 6(d), option A). Meanwhile when the anion was at high concentrations, a $0.87 \mathrm{~nm} d_{\text {basal }}$ appeared, which suggests a new phase related to the intercalation of an anionic complex with a $\left[\left(\mathrm{HAsO}_{4}\right) \cdot\left(\mathrm{MoS}_{4}\right) \cdot\left(\mathrm{HAsO}_{4}\right)\right]^{6-}$ mode (see Fig. 6(d), option B).

\section{Influence of the particle size of the $\mathrm{LDH}$}

For the LDH adsorbent, it is believed that reducing its particle size can increase its adsorption capacity. Yang et al. ${ }^{\mathbf{9 0}}$ investigated the influence of the particle sizes of LDHs on the As(v) adsorption performance in aqueous solution. The results for As(v) adsorption showed that the $\mathrm{As}(\mathrm{v})$ adsorption rate on a conditioned LDH was associated with its particle size. The As(v) adsorption rate increased with decreasing adsorbent particle size. However, the adsorption capacity of As(v) on a conditioned LDH had no relationship with the particle size. Moreover, the experimental data was fitted to two models. One was the homogeneous surface diffusion model (HSDM), the other was the bidisperse pore model (BPM). HSDM considers the adsorbent particle to be a single particle, the advantage of which is its simplicity and ease for simulations. When the HSDM was used to describe the experimental data, the estimated diffusivity values were shown to increase with increasing particle size. Nevertheless, BPM assumes that the particle is an agglomerate of a number of equal-size, single-crystal microparticles, and provided a better representation of the true pore structure of the LDH. When the BPM was utilized to fit the experimental data, it predicted that diffusivity is particle-sizeindependent.

\section{Influence of the $\mathrm{M}^{2+} / \mathrm{M}^{3+}$ ratio}

It has been reported that the $\mathrm{M}^{2+} / \mathrm{M}^{3+}$ ratio in LDHs can influence their adsorption capacities. Therefore, Wang et al. ${ }^{91}$ explored the influence on $\mathrm{As}(\mathrm{v})$ adsorption using $\mathrm{Mg}-\mathrm{Al}-\mathrm{NO}_{3}$ $\mathrm{LDHs}$ of varying the $\mathrm{Mg} / \mathrm{Al}$ ratio. Firstly, the $\mathrm{Mg}-\mathrm{Al}-\mathrm{NO}_{3} \mathrm{LDHs}$ were synthesized using a constant-pH co-precipitation method with different $\mathrm{Mg} / \mathrm{Al}$ ratios of $2: 1,3: 1$ and $4: 1$. It was found that the maximum uptake capacities for As(v) on the $2: 1,3: 1$ and $4: 1 \mathrm{LDHs}$ were 117,81 and $27 \mathrm{mg} \mathrm{g}^{-1}$, respectively, which follows the order of their layer charge densities. Thus, in order to clarify the structural implications of the differences in As(v) adsorption of the various LDHs, the XRD patterns of the LDH samples before and after As(v) adsorption were investigated. It can be observed that the basal spacings of the original $\mathrm{LDH}$ with $\mathrm{Mg}^{2+} / \mathrm{Al}^{3+}$ molar ratios of 2,3 , and 4, were 8.78, 8.13, and $7.95 \AA$, respectively. After interacting with $\mathrm{As}(\mathrm{v})$, the basal spacings of the $2: 1$ and $3: 1$ LDHs became smaller than those of the original, and had shifted to 8.48 and $7.83 \AA$, respectively. However, there was no significant change for the $4: 1 \mathrm{LDH}$ after $\mathrm{As}(\mathrm{v})$ adsorption. Thus, the $\mathrm{LDH}$ with a $\mathrm{Mg}^{2+} / \mathrm{Al}^{3+}$ molar ratio of 4 has a low As(v) adsorption capacity, in combination with no change in the basal spacing after As(v) adsorption, which indicated that $\mathrm{As}(\mathrm{v})$ had relatively little access to the small interlayer space in the $4: 1 \mathrm{LDH}$ due to the horizontal orientation of the interlayer nitrate with respect to the hydroxide sheets. Therefore, it was speculated that $\operatorname{As}(\mathrm{v})$ had adsorbed only on the external surface of the $4: 1 \mathrm{LDH}$ particles for the range of initial As(v) concentration used in this study (see Fig. 7(a)). Consequently, the $4: 1 \mathrm{LDH}$ had maximum As(v) adsorption at a low initial concentration of As(v), which was much less than those of the $2: 1$ and $3: 1$ LDHs. Conversely, for the $2: 1$ and $3: 1$ LDHs, there were changes in the basal spacings after As(v) adsorption, which indicated partial replacement of the interlayer nitrate ions by As(v) ions. The results from XRD showed that the $2: 1$ $\mathrm{LDH}$ has the largest basal spacing due to the perpendicular orientation of the interlayer nitrate with respect to the hydroxide layers in the material. The large basal spacing of the $2: 1 \mathrm{LDH}$ facilitates the diffusion of nitrate and As(v) molecules into its interlayer space. Thus, in conjunction with adsorption on the external surface, the interlayer nitrate ions could be replaced by $\mathrm{As}(\mathrm{v})$ for the positively-charged binding sites in the hydroxide sheets (as shown in Fig. 7(a)), which consequently led to better $\mathrm{As}(\mathrm{v})$ uptake performance. It was suggested that the $3: 1 \mathrm{LDH}$ is an intermediate phase, containing nitrate ions with both parallel and perpendicular orientations. Therefore, they hypothesized that the interlayer nitrate ions with a perpendicular orientation contribute to $\mathrm{As}(\mathrm{v})$ adsorption of the $3: 1 \mathrm{LDH}$, while those with a parallel orientation are not replaced and remain in the structure (see Fig. 7(a)). Therefore, As(v) adsorption on the $2: 1$ and $3: 1$ LDHs occurred by the same reaction mechanism, with different surface availabilities for As(v). The local structure of adsorbed As(v) on various LDHs was further determined using results from the XANES and EXAFS as shown in Fig. 7(b). It can be seen that the absorption edges of As adsorbed by various LDHs were all located at $11875 \mathrm{eV}$, which 


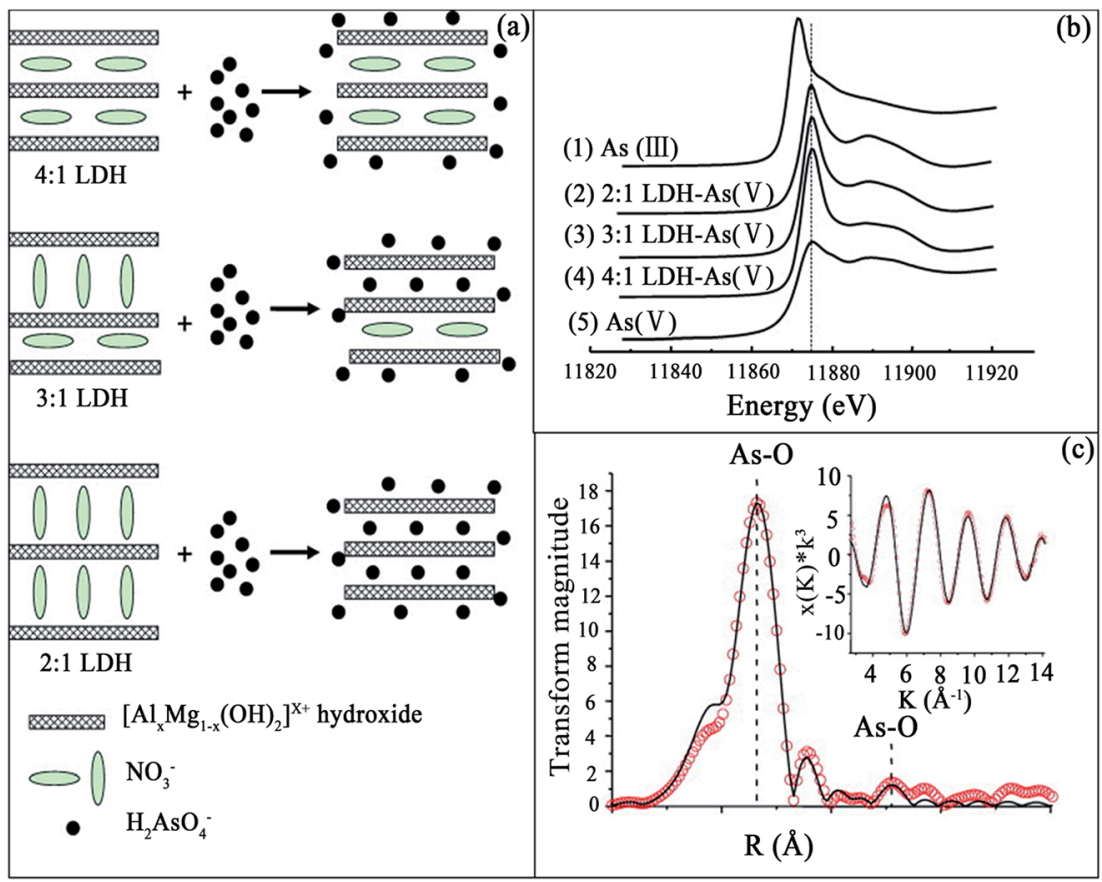

Fig. 7 (a) A schematic representation of the As(v) adsorption mechanisms for the $2: 1,3: 1$ and $4: 1$ LDHs; (b) the As K-edge XANES spectra of (1) the As(III) standard, (2) the $2: 1 \mathrm{LDH}-\mathrm{As}(\mathrm{v})$, (3) the $3: 1 \mathrm{LDH}-\mathrm{As}(\mathrm{v})$, (4) the $4: 1 \mathrm{LDH}-\mathrm{As}(\mathrm{v})$, and (5) the As(v) standard; (c) $k^{3} x(k)$ spectrum and RDF profile derived from the As K-edge EXAFS of As(v) adsorbed on the $2: 1 \mathrm{LDH}$. The solid lines and open circles represent fitted and experimental data, respectively, without phase shift correction (adapted with permission from ref. 91).

was the same as the value determined for $\mathrm{Na}_{2} \mathrm{HAsO}_{4}$, but different from that for $\mathrm{NaAsO}_{2}$. This indicated that there was no reduction of $\operatorname{As}(\mathrm{v})$ to $\mathrm{As}(\mathrm{III})$ after $\mathrm{As}(\mathrm{v})$ adsorption on the LDHs, and that the corresponding local structures of adsorbed As(v) on various LDHs were not different, according to their XANES spectra. The $k^{3}$-weighting oscillation function and RDF profile with peak positions (without phase shift correction), derived from the EXAFS of As(v) adsorbed on the $2: 1 \mathrm{LDH}$ are shown in
Fig. 7(c). The peak positions presented in Fig. 7(c) correspond to the radial distances from As to atoms at different coordination shells. The structural parameters were fitted, including the coordination number $(\mathrm{CN})$, inter-atomic distance $(R)$, and Debye-Waller factor $\left(\sigma^{2}\right)$. The first coordination shell was attributed to the $\mathrm{As}(\mathrm{v})-\mathrm{O}$ interatomic distance of $1.70 \pm 0.02 \AA$, with a $\mathrm{CN}$ of 4 . This is consistent with the molecular structure of an As(v) ion. Furthermore, the interatomic distance between As
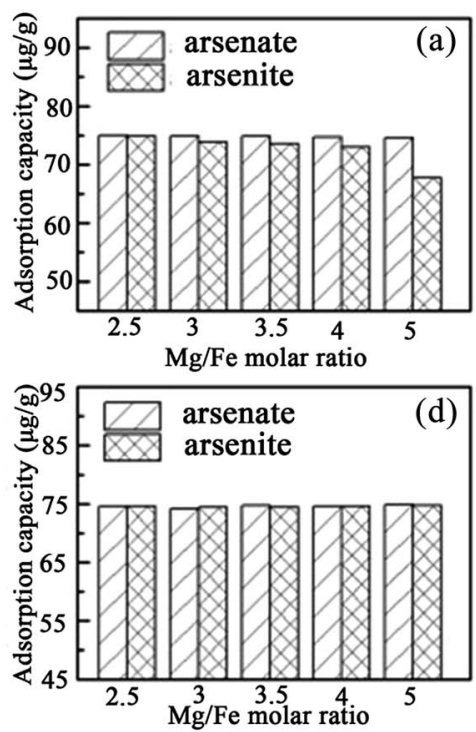
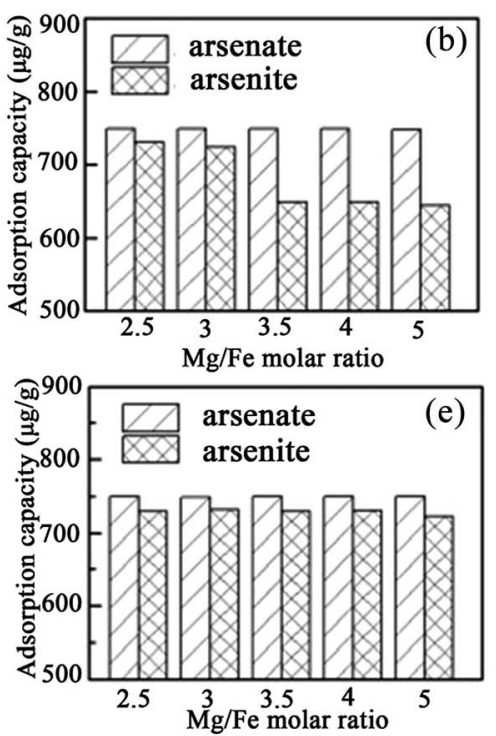
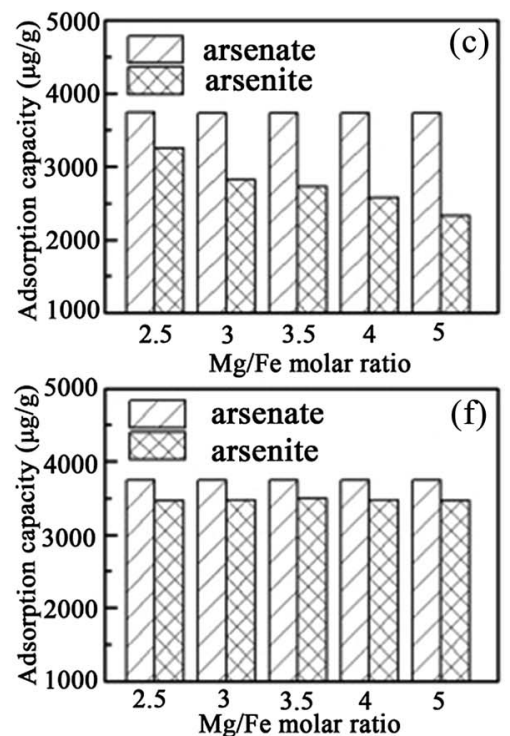

Fig. 8 Comparison of the adsorption capacity between the uncalcined $(a-c)$ and calcined $(d-f)$ iowaites. $(a-c)$ or $(d-f)$ correspond to the initial arsenic concentrations in solution of 150,1500 , and $7500 \mu \mathrm{g} \mathrm{L}^{-1}$, respectively (reproduced with permission from ref. 92). 
and the second-shell atom was determined to be $2.92 \pm 0.07 \AA$, with a $\mathrm{CN}$ of 2.0. These data cannot be fitted to $\mathrm{Al}$ or $\mathrm{Mg}$ as the second shell atoms from As, but a good fit could be obtained if this interatomic distance of $2.92 \AA$ was attributed to that between As and $\mathrm{O}$. This result reveals that no direct chemical bond is formed between the adsorbed $\mathrm{As}(\mathrm{v})$ and the $\mathrm{Al}$ or $\mathrm{Mg}$ sites in the hydroxide sheets of the LDH. Thus, As(v) ions were adsorbed on the external and internal surfaces of the LDHs by predominantly forming outer-sphere complexes, and the $\mathrm{O}$ atom of the second shell might be assigned to the surface $\mathrm{OH}$ groups of the hydroxide layers. The results of this study have demonstrated that selective retention of As(v) from water can be maximized by controlling the orientation of interlayer nitrate in $\mathrm{Mg}-\mathrm{Al}-\mathrm{NO}_{3}$ LDHs.

Recently, Guo et al. ${ }^{92,93}$ used iowaite (a Mg-Fe LDH) for both As(III) and As(v) removal for the first time, and investigated the influence on the uptake capacity of the $\mathrm{Mg} / \mathrm{Fe}$ ratio. It was found that the $\mathrm{Mg} / \mathrm{Fe}$ ratio had little influence on $\mathrm{As}(\mathrm{v})$ removal with the uncalcined iowaites, but played a crucial role in adsorption of As(III) from the solutions (see Fig. 8). The As(III) removal and reaction rate in solution using iowaite decreased with the increase of its $\mathrm{Mg} / \mathrm{Fe}$ molar ratio. However, for the calcined iowaites, their initial $\mathrm{Mg} / \mathrm{Fe}$ ratios and adsorption capacities for both As(v) and As(III) were independent (see Fig. 8). Therefore, it was suggested that the removal of both As(v) and As(III) from solution using uncalcined iowaite may be primarily due to $\mathrm{Fe}-$ As complexation occurring on its surface. However, the calcined iowaites generally had higher As adsorption capacities than the uncalcined iowaites, which was because of the high availability of the interlayer regions for the arsenic oxyanions during the process of structural reconstruction.

\section{LDH-based hybrids}

In recent years, $\mathrm{LDH}$-based hybrids have become promising as adsorbents. ${ }^{53,94,95}$ Nhat Ha et al. ${ }^{96}$ immobilized LDHs in a hybrid polymer system [alginate/polyvinyl alcohol (PVA) in the presence of the cross-linker glutaraldehyde] to synthesize spherical poly(LDH) beads with less distortion for As(v) adsorption. Two kinds of $\mathrm{LDH}$ polymer hybrids (poly $(\mathrm{Mg}-\mathrm{Al})$ and poly $(\mathrm{Mg}-\mathrm{Fe})$ ) were synthesized for As(v) removal. The As(v) adsorption rate of the poly $(\mathrm{Mg}-\mathrm{Al})$ and poly $(\mathrm{Mg}-\mathrm{Fe})$ beads could reach $91.2 \%$ and $79.1 \%$ from an $\mathrm{As}(\mathrm{v})$ solution (with an initial concentration of $50 \mathrm{mg} \mathrm{\textrm {L } ^ { - 1 }}$ ), respectively. As calculated from the Langmuir adsorption isotherm, at $\mathrm{pH} 8$, the adsorption capacities of the poly $(\mathrm{Mg}-\mathrm{Al})$ and poly $(\mathrm{Mg}-\mathrm{Fe})$ beads were from 1.73 to $1.64 \mathrm{mg}$ of As per $\mathrm{g}$. For the regeneration test, the results showed that the poly(LDH) beads had good cycling stabilities, and their adsorption capacities only decreased by approximately 5-6\% after 5 adsorption-desorption cycles. The As(v) removal rates of the poly $(\mathrm{Mg}-\mathrm{Al})$ and poly $(\mathrm{Mg}-\mathrm{Fe})$ beads remained at 85.4 and $72.7 \%$, respectively, after the fifth regeneration cycle. Moreover, in order to investigate the dynamic behavior of the adsorption column, a study of the fixed-bed column was carried out with real-life arsenic-containing water using a column with a $2 \mathrm{~cm}$ diameter. Then, the poly $(\mathrm{Mg}-\mathrm{Al})$ or poly $(\mathrm{Mg}-\mathrm{Fe})$ beads were packed in the column with a $40 \mathrm{~cm}$ bed depth. The column was in up-flow mode with a volumetric flow rate of $57.32 \mathrm{~cm}^{3}\left(\mathrm{~cm}^{2} \mathrm{~h}\right)$ ${ }^{-1}\left(3.0 \mathrm{~mL} \mathrm{~min}^{-1}\right)$, and was charged with real-life arseniccontaining water. Although both the fixed-bed poly $(\mathrm{Mg}-\mathrm{Al})$ and poly $(\mathrm{Mg}-\mathrm{Fe})$ beads showed decent removal of the problematic $\operatorname{As}(\mathrm{v})$, the results showed that the fixed-bed column of poly $(\mathrm{Mg}-\mathrm{Al})$ displayed better column performance than that of poly $(\mathrm{Mg}-\mathrm{Fe})$, and had longer operation times, treated larger

Table 1 Summary of adsorption capacities for As of LDH derived adsorbents

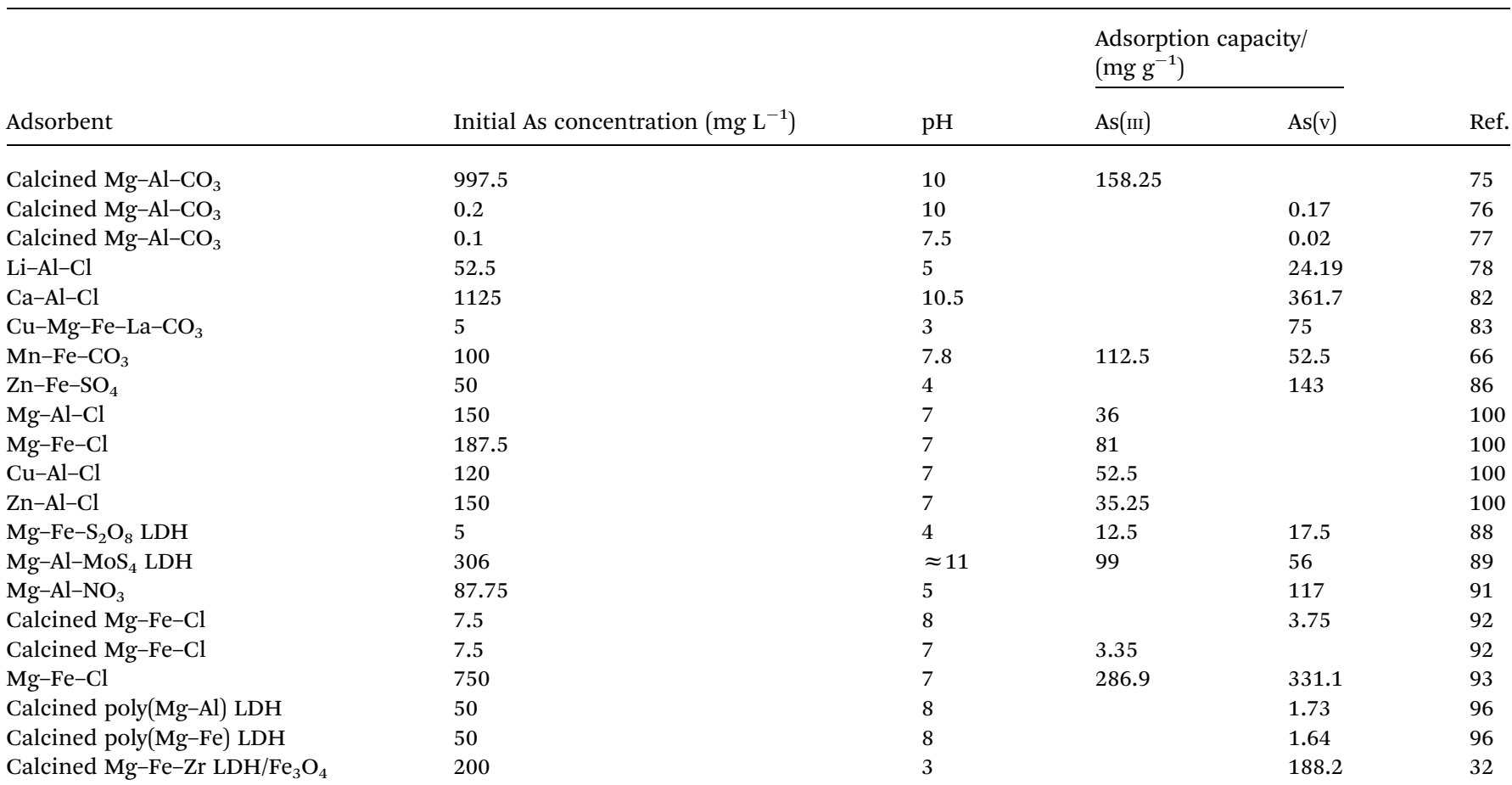


volumes and removed higher quantities of As(v). Following this, Suvokhiaw et al. $^{32}$ prepared magnetic $\mathrm{Mg}-\mathrm{Fe}-\mathrm{Zr} \quad \mathrm{LDH} / \mathrm{Fe}_{3} \mathrm{O}_{4}$ hybrids as adsorbents for $\mathrm{As}(\mathrm{v})$ removal. The $\mathrm{As}(\mathrm{v})$ adsorption ability of the pure $\mathrm{Mg}-\mathrm{Fe}-\mathrm{Zr} \mathrm{LDH}(\mathrm{LDH})$, bare $\mathrm{Fe}_{3} \mathrm{O}_{4}$, and the $\mathrm{Mg}-\mathrm{Fe}-\mathrm{Zr} \quad \mathrm{LDH} / \mathrm{Fe}_{3} \mathrm{O}_{4}$ hybrid $(\mathrm{m}-\mathrm{LDH})$ and their calcined counterparts were compared. The results showed that the calcined $\mathrm{LDH}$ and calcined $\mathrm{m}-\mathrm{LDH}$ possessed higher adsorption amounts than their noncalcined counterparts due to the increase in surface area after calcination. In the case of the iron oxides, their surface areas decreased dramatically after calcination due to phase transformation and particle aggregation, resulting in lower adsorption capacities. In addition, the calcined $\mathrm{m}-\mathrm{LDH}$ (188 $\left.\mathrm{mg} \mathrm{g}^{-1}\right)$ showed lower adsorption than the calcined LDH (203 $\mathrm{mg} \mathrm{g}^{-1}$ ), because the hybrid contained the $\mathrm{Fe}_{3} \mathrm{O}_{4}$ phase. However, the as-synthesized m-LDH hybrid and calcined $\mathrm{m}$-LDH could be separated from the aqueous solution using an external magnetic field. The two-step mechanism of the adsorption behavior was proposed as: (i) the structural reconstruction of the mixed metal oxides to $\mathrm{LDH}$ layers, and (ii) the anion exchange of hydroxides inside the reformed $\mathrm{LDH}$ galleries.

All the LDH derived adsorbents and their performance in As removal available in the literature are summarized in Table 1. Since the As adsorbents' removal capacities were evaluated at different As concentration ranges, temperatures, $\mathrm{pH}$ values, adsorbent doses and $\mathrm{As}(\mathrm{III}) / \mathrm{As}(\mathrm{v})$ ratios etc., it is very difficult to directly compare these adsorption capacities with those of other As adsorbents. In Mohan's paper, they gave a summary showing that some low-cost adsorbents developed from agricultural waste or industrial waste have outstanding capacities. For instance, the As adsorption capacity of immobilized biomass can reach more than $700 \mathrm{mg} \mathrm{g}^{-1}$, while basic yttrium carbonate and goethite also have high As removal abilities of as much as $400 \mathrm{mg} \mathrm{g}^{-1}$. Some commercial adsorbents, which include resins, gels, silica and titanium dioxide, tested for As removal have an As removal capacity of 100-200 $\mathrm{mg} \mathrm{g}^{-1}$. $^{2}$ However, LDHs also performed well in As removal, and values can reach as high as $361.7 \mathrm{mg} \mathrm{g}^{-1}$, which are comparable to those of the other adsorbents. Besides their removal ability, the cost of the adsorbent is also very significant. ${ }^{97}$ The cost of the adsorbent is mainly dependent on the availability of each type, and their preparation and applicability in actual field conditions. ${ }^{98}$ Although waste material derived adsorbents seem inexpensive, their pretreatment and chemical modification costs are seldom mentioned in research papers. In addition, most research has focused on laboratory evaluations. Jessica et al. ${ }^{99}$ have summarized the cost effectiveness of selected As avoidance methods. Reverse osmosis (\$411 annually) was the most cost effective, followed by activated alumina (\$518) and 1-gal jugs of water (\$321-1285) for households with more than one person.

\section{Competition with other ions}

It is known that environmental As is always accompanied by other ions in contaminated water. When competitive ions exist, the solid-liquid adsorption equilibrium will be changed, and a new set of isotherms will emerge. ${ }^{2}$ In particular, for LDHs, the effect of competing anions on the adsorption of As may be related to the anion affinity or anion intercalation capability of the $\mathrm{LDH},{ }^{\mathbf{1 0 1 , 1 0 2}}$ while the desorption rates correspond to the different anion affinities for the $\mathrm{LDH}^{.{ }^{\mathbf{1 0 3}}}$ Therefore, the adsorption behavior of As with LDHs in the presence of multicomponent impurities has been studied by researchers. You et $a .^{75}$ investigated the influence of the presence of additional anions on the adsorption of As(III) using LDHs in water. It was found that other anions present had strong interactions with the calcined LDH, affecting As(III) adsorption. The As(III) adsorption capacity was in the following order: $\mathrm{HPO}_{4}{ }^{2-}<\mathrm{SO}_{4}{ }^{2-}$ $<\mathrm{CO}_{3}{ }^{2-}<\mathrm{F}^{-}<\mathrm{Cl}^{-}<\mathrm{Br}^{-}<\mathrm{NO}_{3}{ }^{-}$. Nevertheless, the desorption results showed that $\mathrm{As}(\mathrm{III})$ could be desorbed by different anions after adsorption on calcined LDHs, but there was no systematic relationship between As(III) desorption and the anion affinities for the calcined LDHs. For bivalent anions $\left(\mathrm{CO}_{3}{ }^{2-}\right.$ and $\left.\mathrm{SO}_{4}{ }^{2-}\right)$, As(III) release can reach a plateau after 8 iterations, however, the desorbed As(III) (78 $\mathrm{mg} \mathrm{g}^{-1}$ ) was less than that of the adsorbed As(III) (165.6 $\mathrm{mg} \mathrm{g}^{-1}$ ) on the calcined LDH. Meanwhile for monovalent anions $\left(\mathrm{NO}_{3}{ }^{-}\right.$and $\left.\mathrm{Cl}^{-}\right)$, with the desorption times increasing, the desorption of As(III) increased continually. However, in $\mathrm{HPO}_{3}{ }^{-}$solution, the desorption rate was very slow. Following this, Yang et al. ${ }^{76}$ studied the influence of competitive anions on the removal of As(v) using a calcined LDH. The results indicated that $\mathrm{NO}_{3}{ }^{-}$had almost no influence on the uptake of As(v) on the calcined $\mathrm{LDH}$, while $\mathrm{SO}_{4}{ }^{2-}, \mathrm{CO}_{3}{ }^{2-}$ and $\mathrm{HCO}_{3}{ }^{-}$had a modest effect, and $\mathrm{HPO}_{4}{ }^{2-}$ had the most negative impact on the uptake of $\mathrm{As}(\mathrm{v})$ on the calcined LDH. In addition, it was proven that competing ions had a stronger effect on the uptake by uncalcined LDH than on that by calcined LDH.

Moreover, Caporale et al. ${ }^{104}$ studied the competition between $\mathrm{AsO}_{4}{ }^{3-}$ and organic and inorganic ligands for the adsorption sites on two kinds of $\mathrm{LDH}$, which were $\mathrm{Mg}-\mathrm{Al} \mathrm{LDH}$ and $\mathrm{Mg}-\mathrm{Fe}$ LDH. Specifically, they examined $\mathrm{AsO}_{4}{ }^{3-}$ adsorption on the $\mathrm{Mg}-$ $\mathrm{Al} \mathrm{LDH}$ and the $\mathrm{Mg}-\mathrm{Fe} \mathrm{LDH}$, as affected by the $\mathrm{pH}$. Various concentrations of inorganic [nitrate $\left(\mathrm{NO}_{3}{ }^{-}\right)$, nitrite $\left(\mathrm{NO}_{2}{ }^{-}\right)$, phosphate $\left(\mathrm{PO}_{4}{ }^{3-}\right)$ and selenite $\left(\mathrm{SeO}_{3}{ }^{2-}\right)$, sulphate $\left.\left(\mathrm{SO}_{4}{ }^{2-}\right)\right]$ and organic [oxalate $\left(\mathrm{OX}^{2-}\right)$ and tartrate $\left(\mathrm{TAR}^{2-}\right)$ ] ligands were used. The adsorption isotherm results showed that the $\mathrm{Mg}-\mathrm{Fe} \mathrm{LDH}$ had better $\mathrm{AsO}_{4}{ }^{3-}$ adsorption performance than the $\mathrm{Mg}-\mathrm{Al}$ LDH. Moreover, with different competing anions in the solution, the $\mathrm{AsO}_{4}{ }^{3-}$ adsorption efficiency of the two LDHs was also different. The efficiency of the anions in competing with $\mathrm{AsO}_{4}{ }^{3-}$ for the adsorption sites on the $\mathrm{Mg}-\mathrm{Al} \mathrm{LDH}$ was in the order $\mathrm{NO}_{3}{ }^{-}<\mathrm{NO}_{2}{ }^{-}<\mathrm{SO}_{4}{ }^{2-}<\mathrm{SeO}_{3}{ }^{2-}<\mathrm{TAR}^{2-}<\mathrm{OX}^{2-} \leq \mathrm{PO}_{4}{ }^{3-}$ at all molar ratios examined (see Fig. 9A), while on the $\mathrm{Mg}-\mathrm{Fe} \mathrm{LDH}$ the order was $\mathrm{NO}_{3}{ }^{-}<\mathrm{SO}_{4}{ }^{2-} \approx \mathrm{NO}_{2}{ }^{-}<\mathrm{TAR}^{2-}<\mathrm{OX}^{2-}<\mathrm{SeO}_{3}{ }^{2-} \leq$ $\mathrm{PO}_{4}{ }^{3-}$ (see Fig. 9B). The inhibition of $\mathrm{AsO}_{4}{ }^{3-}$ adsorption increased with increasing initial ligand concentration and was greater on the $\mathrm{Mg}-\mathrm{Al} \mathrm{LDH}$ than on the $\mathrm{Mg}-\mathrm{Fe} \mathrm{LDH}$, evidently because the $\mathrm{AsO}_{4}{ }^{3-}$ anions had a stronger affinity for $\mathrm{Fe}$ than $\mathrm{Al}$ and due to the presence in the $\mathrm{Mg}-\mathrm{Fe} \mathrm{LDH}$ of short-rangeordered materials on which $\mathrm{AsO}_{4}{ }^{3-}$ forms very strong innersphere complexes which are not easily desorbed by competing ligands. ${ }^{105-107}$ The effect of residence time on the desorption capacity of $\mathrm{AsO}_{4}{ }^{3-}$ LDHs due to these ligands was also investigated. At all the examined residence times, the results showed 
that the ability of the anions to desorb $\mathrm{AsO}_{4}{ }^{3-}$ from the adsorption sites on the $\mathrm{Mg}-\mathrm{Al} \mathrm{LDH}$ was in the order $\mathrm{NO}_{3}{ }^{-}<$ $\mathrm{NO}_{2}{ }^{-}<\mathrm{SeO}_{3}{ }^{2-} \approx \mathrm{SO}_{4}{ }^{2-}<\mathrm{TAR}^{2-}<\mathrm{OX}^{2-} \leq \mathrm{PO}_{4}{ }^{3-}$, while on the $\mathrm{Mg}-\mathrm{Fe} \mathrm{LDH}$, the order was different: $\mathrm{NO}_{3}{ }^{-}<\mathrm{SO}_{4}{ }^{2-} \approx \mathrm{NO}_{2}{ }^{-}<$ $\mathrm{TAR}^{2-} \leq \mathrm{OX}^{2-}<\mathrm{SeO}_{3}{ }^{2-} \leq \mathrm{PO}_{4}{ }^{3-}$. Nevertheless, the influence of increasing residence time on the desorbing of $\mathrm{AsO}_{4}$ was similar for all the ligands, for both LDHs, varying from 2 to $10 \%$. However, for the $\mathrm{Mg}-\mathrm{Al} \mathrm{LDH}$ systems, with $\mathrm{PO}_{4}{ }^{3-}, \mathrm{TAR}^{2-}$ and $\mathrm{OX}^{2-}, 10-20 \%$ more $\mathrm{AsO}_{4}{ }^{3-}$ was desorbed compared to the $\mathrm{Mg}$ Fe LDH systems for the same residence time. It was suggested that $\mathrm{AsO}_{4}{ }^{3-}$ was bonding more strongly to the $\mathrm{Mg}-\mathrm{Fe} \mathrm{LDH}$ than the $\mathrm{Mg}-\mathrm{Al} \mathrm{LDH}$. Therefore the $\mathrm{AsO}_{4}{ }^{3-}$ was more easily desorbed on the $\mathrm{Mg}-\mathrm{Al} \mathrm{LDH}$ in comparison with that on the $\mathrm{Mg}-\mathrm{Fe} \mathrm{LDH}$. Recently, Nhat Ha et al. ${ }^{96}$ tested the effect of co-existing anions on $\mathrm{As}(\mathrm{v})$ adsorption using poly $(\mathrm{Mg}-\mathrm{Al} \mathrm{LDH}, \mathrm{Mg}-\mathrm{Fe} \mathrm{LDH})$
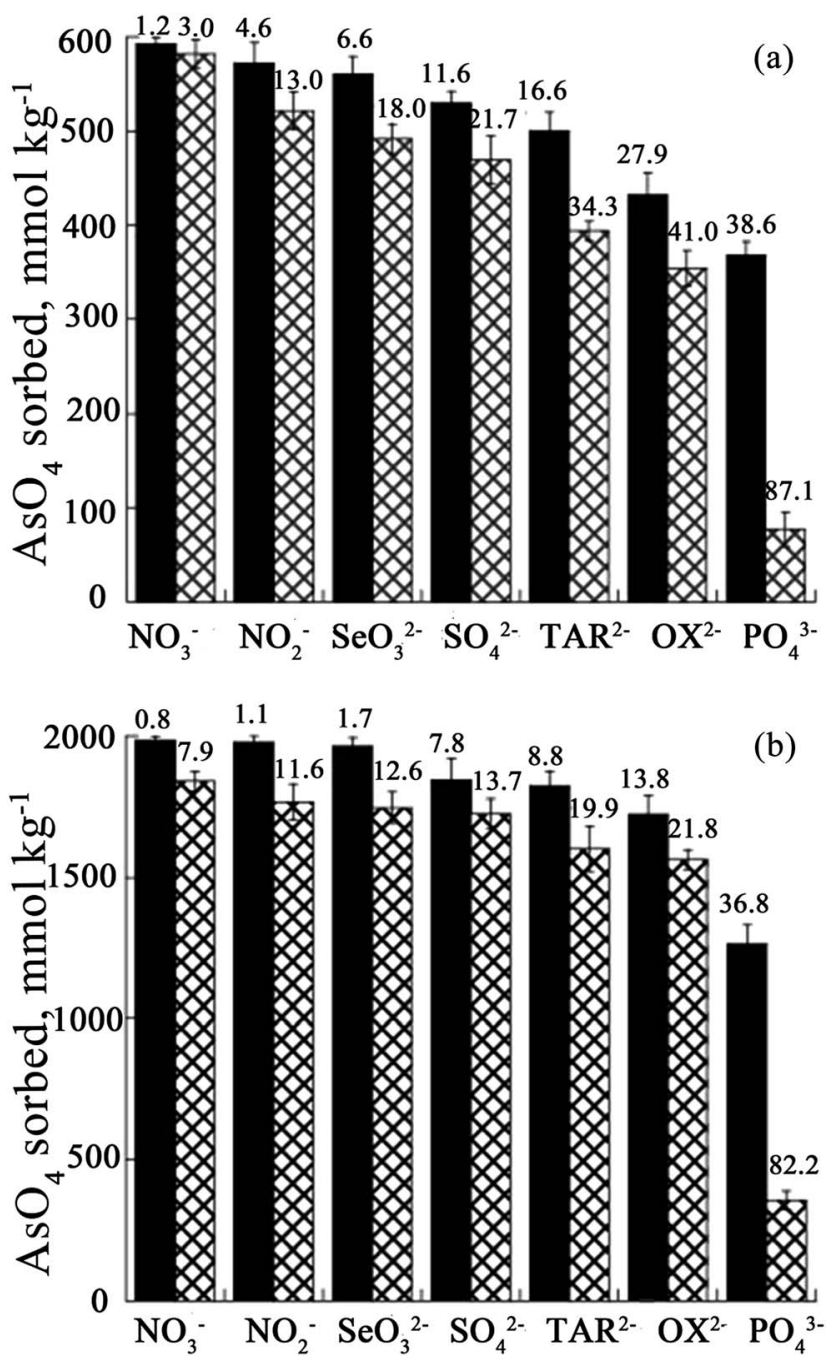

Fig. 9 The amount of $\mathrm{AsO}_{4}$ sorbed onto the $\mathrm{Mg}-\mathrm{Al} \mathrm{LDH}(\mathrm{A})$ and $\mathrm{Mg}-$ $\mathrm{Fe} \mathrm{LDH} \mathrm{(B)} \mathrm{in} \mathrm{the} \mathrm{presence} \mathrm{of} \mathrm{increasing} \mathrm{concentrations} \mathrm{of} \mathrm{inorganic}$ and organic ligands after a reaction time of $24 \mathrm{~h}$; initial ligand $/ \mathrm{AsO}_{4}$ molar ratios $=1$ (black) and 5 (checkered white). The numbers indicate the efficiency (\%) of the ligands in preventing $\mathrm{AsO}_{4}$ sorption. The initial $\mathrm{AsO}_{4}$ concentrations for the $\mathrm{Mg}-\mathrm{Al} \mathrm{LDH}$ and the $\mathrm{Mg}-\mathrm{Fe} \mathrm{LDH}$ were 600 and $2000 \mathrm{mmol} \mathrm{kg}^{-1}$, respectively (reproduced with permission from ref. 104). hybrids. It was found that phosphate and carbonate markedly decreased the removal of As(v). The effects of coexisting anions on the adsorption capacity declined in the following order: $\mathrm{HPO}_{4}{ }^{2-}>>\mathrm{HCO}_{3}{ }^{-}>\mathrm{SO}_{4}{ }^{2-}>\mathrm{Cl}^{-}$. Furthermore, Ardau et al. ${ }^{108}$ tested synthetic $\mathrm{Zn}-\mathrm{Al}$-sulphate $\mathrm{LDH}$ for As removal from aqueous systems through adsorption experiments. In order to assess the influence of competition on As removal, a series of aqueous solutions containing dissolved $\mathrm{HAsO}_{4}{ }^{2-}$ together with other anions $\left(\mathrm{Cl}^{-}, \mathrm{SO}_{4}{ }^{2-}, \mathrm{MoO}_{4}{ }^{2-}, \mathrm{HCO}_{3}{ }^{-}\right.$and $\left.\mathrm{CO}_{3}{ }^{2-}\right)$ were prepared. The competitors were added into the solution simultaneously and afterwards with respect to $\mathrm{HAsO}_{4}{ }^{2-}$ in order to verify the effectiveness and possible reversibility of the As sorption process. The experimental results also confirmed that As adsorption from the solution was mostly by ion exchange processes, due to the strong capability of As in replacing $S$ in the interlayers of the LDH structure, where anionic groups are hosted, giving rise to heteroanionic compounds. With the competitors, the results showed that $\mathrm{CO}_{3}{ }^{2-}$ had a significant impact on the As adsorption efficacy on LDHs. In fact, up to $\sim 90 \%$ of $\mathrm{HAsO}_{4}{ }^{2-}$ could be removed from the solution, decreasing to $\sim 60 \%$ in the presence of $\mathrm{CO}_{3}{ }^{2-}$, whilst up to $\sim 30 \%$ of $\mathrm{HAsO}_{4}{ }^{2-}$ could be desorbed when $\mathrm{CO}_{3}{ }^{2-}$ was added afterwards into the solution. Since a very restricted $\mathrm{pH}$ range was used (c. pH 10-11.5), where $\mathrm{HAsO}_{4}{ }^{2-}$ and $\mathrm{CO}_{3}{ }^{2-}$ were simultaneously the predominant species in the solution, they thought that $\mathrm{Zn}-\mathrm{Al}$-sulphate LDHs could be successfully used for the treatment of As contaminated water with $\mathrm{pH}$ values ranging from circum-neutral to moderately alkaline. In addition, Bagherifam et al. ${ }^{85}$ carried out an investigation of the effects of two kinds of competing divalent anion $\left(\mathrm{SO}_{4}{ }^{2-}\right.$ and $\mathrm{CO}_{3}{ }^{2-}$ ) on the adsorption of As(III) and As(v). From Fig. 10, it can be seen that the As(III) removal rate decreased from 69 to 61 and $54 \%$, however, the As(v) uptake rate decreased only from 88 to 86 and $82 \%$, in the presence of $1 \mathrm{mM} \mathrm{Na} \mathrm{SO}_{4}$ or $\mathrm{Na}_{2} \mathrm{CO}_{3}$, respectively. This clearly proved that the adsorption capacity for As(III) was more affected by the presence of competing anions than that for $\mathrm{As}(\mathrm{v})$. Moreover, $\mathrm{CO}_{3}{ }^{2-}$ had a greater effect on $\mathrm{As}(\mathrm{III})$ and $\mathrm{As}(\mathrm{V})$ adsorption than $\mathrm{SO}_{4}{ }^{2-}$.

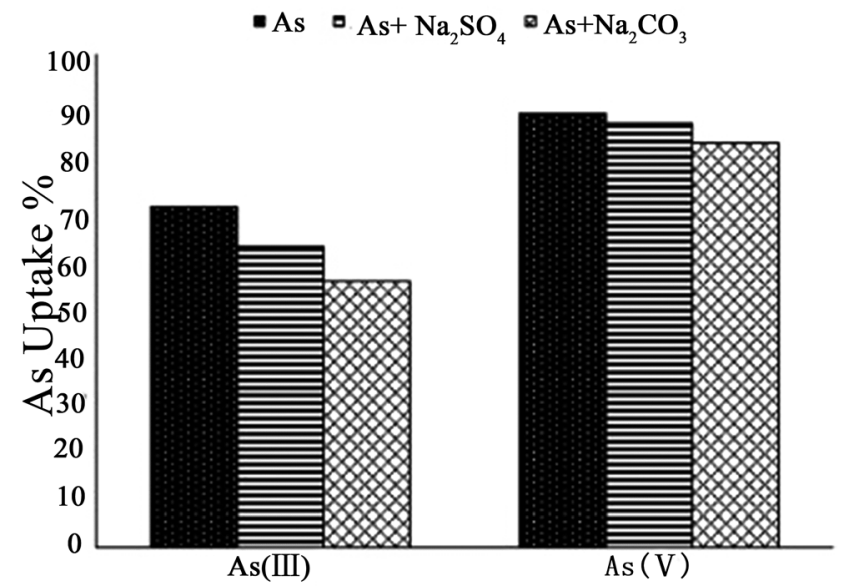

Fig. 10 The effect of competitive anions on the As(III) and $\mathrm{As}(\mathrm{V})$ uptakes using the $\mathrm{Zn}-\mathrm{Al}-\mathrm{SO}_{4} \mathrm{LDH}$ (reproduced with permission from ref. 85). 
Very recently, Pigna et al. ${ }^{\mathbf{1 0 0}}$ prepared $\mathrm{Cu}-\mathrm{Al}, \mathrm{Mg}-\mathrm{Al}, \mathrm{Mg}-\mathrm{Fe}$, and $\mathrm{Zn}-\mathrm{Al}$ LDHs as As adsorbents to investigate the As(III) removal efficiency in the presence of competing inorganic anions (i.e., $\mathrm{CO}_{3}{ }^{2-}, \mathrm{SO}_{4}{ }^{2-}, \mathrm{PO}_{4}{ }^{3-}, \mathrm{Cl}^{-}$and $\mathrm{F}^{-}$), which are commonly present in bodies of water. The results confirmed that the nature and reactivity of the $\mathrm{LDH}$ adsorbents on As(III) removal depended on the composition of the $\mathrm{LDH}$ with divalent ( $\mathrm{Mg}$ vs. $\mathrm{Zn}$ or $\mathrm{Cu}$ ) and trivalent (Fe vs. $\mathrm{Al}$ ) cations. Moreover, without other competing anions, the efficiency of the competing anions for inhibiting the As(III) adsorption of the LDHs was $\mathrm{Cl}^{-} \leq \mathrm{F}^{-}<\mathrm{SO}_{4}{ }^{2-} \ll \mathrm{CO}_{3}{ }^{2-} \ll \mathrm{PO}_{4}{ }^{3-}$, regardless of the initial ligand/As(III) molar ratio or the $\mathrm{LDH}$. The results showed that the $\mathrm{Mg}-\mathrm{Fe}-\mathrm{LDH}$ had the highest $\mathrm{As}(\mathrm{III})$ adsorption capacity, nevertheless, the $\mathrm{Cu}-\mathrm{Al} \mathrm{LDH}$ showed a higher affinity for As(III) in the presence of competing anions. Hence, in order to achieve in situ oxidation of $\mathrm{As}(\mathrm{III})$ and to remove both $\mathrm{As}(\mathrm{v})$ and $\mathrm{As}(\mathrm{III})$ simultaneously, the $\mathrm{Cu}-\mathrm{Al} \mathrm{LDH}$ may be a better As adsorbent than the $\mathrm{Mg}-\mathrm{Fe} \mathrm{LDH}$ in contaminated water where competing anions occur in high molar ratios to As(III).

\section{Conclusions}

In this review, the progress in research on LDHs as As adsorbents has been thoroughly reviewed in five parts. It has indicated that As adsorption can more easily occur on calcined LDHs than on uncalcined LDHs by the anion exchange and reconstruction mechanisms. Moreover, the $\mathrm{LDH}$ synthesis method may impact its As adsorption performance. LDHs synthesized using the coprecipitation method displayed higher As uptake capacities than those synthesized using the hydrothermal method. The research results verified that the composition of the LDH influences the As adsorption capacity and corresponds to the cations and anions in the LDH. In addition, the $\mathrm{Mg} / \mathrm{Al}$ ratio has a strong influence on the adsorption capacity of LDHs, because of the different layer charge densities in LDHs. For LDH-based hybrids, polymer LDH hybrids showed excellent As adsorption and regeneration abilities. Meanwhile, the $\mathrm{Mg}-\mathrm{Fe}-\mathrm{Zr} \mathrm{LDH} / \mathrm{Fe}_{3} \mathrm{O}_{4}$ hybrid showed a little lower As adsorption capacity because the hybrid contained the $\mathrm{Fe}_{3} \mathrm{O}_{4}$ phase. However, the hybrid could be separated from the aqueous solution using an external magnetic field. In addition, the influence of competing anions on the adsorption of As on LDHs relates to the anion affinity or anion intercalation capability of the LDH. Meanwhile, the desorption rate is associated with the different anion affinities for LDHs. Except for the influencing factors, the As adsorption capacity of LDHs also depends on the As concentration and adsorbent dose, as well as the other elements and their concentrations in water. The $\mathrm{pH}$ of water can influence the removal ability of As of LDHs. As removal using LDHs is very sensitive to the $\mathrm{pH}$ when the $\mathrm{pH}$ is relatively low, however, it is insensitive to the $\mathrm{pH}$ when the $\mathrm{pH}$ is above 7.0.

Clearly, LDHs as As adsorbents have been studied across a broad range, however, to further improve the As adsorption capacity is also of first importance for future research. In addition, future research must focus on developing molecular models based on actual pollution water. For the practical use of an adsorbent, the regeneration of the adsorbent is very important, which is associated with the cost. Therefore, the regeneration ability and techno-economic assessment of LDHs as As adsorbents will be focused on in the future, which may provide solutions for understanding the adsorption mechanism and carrying out economic evaluations of $\mathrm{LDH}$ derived adsorbents.

\section{Conflicts of interest}

There are no conflicts to declare.

\section{Acknowledgements}

This study was funded by the Scientific Research Fund Projects of the Yunnan Provincial Department of Education (2017ZZX137) and the National Natural Science Foundation of China (51568067, 51622801 and 51572029). We are very grateful to all member units of the project team for their help.

\section{References}

1 B. K. Mandal and K. T. Suzuki, Talanta, 2002, 58, 201.

2 D. Mohan and C. U. Pittman Jr, J. Hazard. Mater., 2007, 142, 1.

3 K. Wu, H. Wang, R. Liu, X. Zhao, H. Liu and J. Qu, J. Hazard. Mater., 2011, 18, 990.

4 C. M. Babu, B. Palanisamy, B. Sundaravel, K. Shanthi and V. Murugesan, Sci. Adv. Mater., 2015, 7, 794.

5 M. A. Rosa, J. A. Egido and M. C. Márquez, J. Taiwan Inst. Chem. Eng., 2017, 78, 409.

6 M. Leist, R. J. Casey and D. Caridi, J. Hazard. Mater., 2000, 76, 125.

7 P. Nakseedee, V. Tanboonchuy, N. Pimpha, P. Khemthong, C. H. Liao and N. Grisdanurak, J. Taiwan Inst. Chem. Eng., 2015, 47, 182.

8 J. C. Ng, J. Wang and A. Shraim, Chemosphere, 2003, 52, 1353.

9 K. Wu, R. P. Liu, H. J. Liu, H. C. Lan and J. H. Qu, J. Hazard. Mater., 2012, 239, 308.

10 P. L. Smedley and D. G. Kinniburgh, Appl. Geochem., 2002, $17,517$.

11 D. B. Singh, G. Prasad, D. C. Rupainwar and V. N. Singh, Water, Air, Soil Pollut., 1988, 42, 373.

12 WHO, Environmental Health Criteria 224: Arsenic compounds, 2nd edn, 2011.

13 C. K. Jain and I. Ali, Water Res., 2000, 34, 4304.

14 M. Vaclavikova, G. P. Gallios, S. Hredzak and S. Jakabsky, Clean Technol. Environ. Policy, 2008, 10, 89.

15 U. Shafique, A. Ijaz, M. Salman, W. uz Zaman, N. Jamil, R. Rehman and A. Javaid, J. Taiwan Inst. Chem. Eng., 2012, 43, 256.

16 B. Daus, R. Wennrich and H. Weiss, Water Res., 2004, 38, 2948.

17 Y. Sun, G. Zhou, X. Xiong, X. Guan, L. Li and H. Bao, Water Res., 2013, 47, 4340.

18 D. Haraguchi, C. Tokoro, Y. Oda and S. Owada, J. Chem. Eng. Jpn., 2013, 46, 173. 
19 S. Chakrabortty, M. Sen and P. Pal, Environ. Sci. Pollut. Res., 2014, 21, 3840.

20 A. Dominguez-Ramos, K. Chavan, V. García, G. Jimeno, J. Albo, K. V. Marathe, G. D. Yadav and A. Irabien, J. Ind. Eng. Chem., 2014, 53, 18920.

21 B. J. Lafferty and R. H. Loeppert, Environ. Sci. Technol., 2005, 39, 2120.

22 S. Wang, B. Gao, A. R. Zimmerman, Y. Li, L. Ma, W. G. Harris and K. W. Migliaccio, Bioresour. Technol, 2015, 175, 391.

23 S. Wang, B. Gao, Y. Li, A. R. Zimmerman and X. Cao, RSC Adv., 2016, 6, 17792.

24 S. Zhang, H. Niu, Y. Cai, X. Zhao and Y. Shi, Chem. Eng. J., 2010, 158, 599.

25 X. Guo, X. Jin, X. Zhao, Z. Yang, X. Lv, J. Zhang and N. Qiu, Sci. Adv. Mater., 2014, 6, 793.

26 L. Dambies, T. Vincent and E. Guibal, Water Res., 2002, 36, 3699.

27 M. M. Benjamin, R. S. Sletten, R. P. Bailey and T. Bennett, Water Res., 1996, 30, 2609.

28 M. N. Amin, S. Kaneco, T. Kitagawa, A. Begum, H. Katsumata, T. Suzuki and K. Ohta, Ind. Eng. Chem. Res., 2006, 45, 8105.

29 D. Kang, X. Yu, S. Tong, M. Ge, J. Zuo, C. Cao and W. Song, Chem. Eng. J., 2013, 228, 731.

30 S. Paikaray, M. J. Hendry and J. Essilfie-Dughan, Chem. Geol., 2013, 345, 130.

31 K. H. Goh, T. T. Lim and Z. Dong, Water Res., 2008, 42, 1343.

32 S. Suvokhiaw, A. Imyim and N. Sukpirom, Sep. Purif. Technol., 2016, 51, 2948.

33 S. Duan, W. Ma, Z. Cheng, P. Zong, X. Sha and F. Meng, Colloids Surf., A, 2016, 490, 250.

34 Q. Wang and D. O'Hare, Chem. Rev., 2012, 112, 4124.

35 B. Li, Z. Xu, F. Jing, S. Luo, N. Wang and W. Chu, J. Energy Chem., 2016, 25, 1078.

36 S. M. N. Mohsin, M. Z. Hussein and S. H. Sarijo, Sci. Adv. Mater., 2014, 6, 648.

37 T. Wang, J. Li, Y. Su, C. Wang, Y. Gao, L. Chou and W. Yao, J. Energy Chem., 2015, 24, 432.

38 N. D. Hutson, Chem. Mater., 2004, 16, 4135.

39 J.-I. Yang and J. N. Kim, Korean J. Chem. Eng., 2006, 23, 77.

40 P.-H. Chang, T.-J. Lee, Y.-P. Chang and S.-Y. Chen, ChemSusChem, 2013, 6, 1076.

41 S. Radha and A. Navrotsky, J. Phys. Chem. C, 2014, 118, 29836.

42 O. Aschenbrenner, P. McGuire, S. Alsamaq, J. Wang, S. Supasitmongkol, B. Al-Duri, P. Styring and J. Wood, Chem. Eng. Res. Des., 2011, 89, 1711.

43 X. Tong, P. Choi, S. Li, Y. Shi and H. Zhang, RSC Adv., 2016, 6, 98804.

44 Q. Wang, Z. H. Wu, H. H. Tay, L. W. Chen, Y. Liu, J. Chang, Z. Y. Zhong, J. Z. Luo and A. Borgna, Catal. Today, 2011, 164, 198.

45 R. Rojas, Appl. Clay Sci., 2014, 87, 254.

46 F. R. Peligro, I. Pavlovic, R. Rojas and C. Barriga, Chem. Eng. J., 2016, 306, 1035.
47 M. A. González, I. Pavlovic, R. Rojas-Delgado and C. Barriga, Chem. Eng. J., 2014, 254, 605.

48 R. Rojas, Chem. Eng. J., 2016, 303, 331.

49 D. Zhao, G. Sheng, J. Hu, C. Chen and X. Wang, Chem. Eng. J., 2011, 171, 167.

50 M. R. Othman, Z. Helwani and W. J. N. Fernando, Appl. Organomet. Chem., 2009, 23, 335.

51 W. Bao, J. Wang, Q. Wang, D. O'Hare and Y. Wan, Sci. Rep., 2016, 6, 1.

52 J. Wang, X. Mei, L. Huang, Q. Zheng, Y. Qiao, K. Zang, S. Mao, R. Yang, Z. Zhang, Y. Gao, Z. Guo, Z. Huang and Q. Wang, J. Energy Chem., 2015, 24, 127.

53 J. Wang, L. Huang, Q. Zheng, Y. Qiao and Q. Wang, J. Ind. Eng. Chem., 2016, 36, 355.

54 L. Wang, Y. Wang and X. Wang, Materials, 2017, 10, 1140. 55 F. Barahuie, M. Z. Hussein and P. Arulselvan, Sci. Adv. Mater., 2016, 8, 501.

56 Q. Qin, J. Wang, T. Zhou, Q. Zheng, L. Huang, Y. Zhang, P. Lu, A. Umar, B. Louis and Q. Wang, J. Energy Chem., 2017, 26, 346.

57 H. M. Kim, K. M. Kim and B. C. Jung, Sci. Adv. Mater., 2014, 6, 1582.

58 X. Shan, Y. Hu and H. Chen, Sci. Adv. Mater., 2015, 7, 1848. 59 P. Lu, X. Zhang and Z. Wang, Sci. Adv. Mater., 2016, 8, 1656. 60 J. Tedim, M. L. Zheludkevich, A. N. Salak, A. Lisenkov and M. G. S. Ferreira, J. Mater. Chem., 2011, 21, 15464.

61 M. L. Zheludkevich, J. Tedim and M. G. S. Ferreira, Electrochim. Acta, 2012, 82, 314.

62 T. L. Galvão, C. S. Neves, M. L. Zheludkevich, J. R. Gomes, J. Tedim and M. G. Ferreira, J. Phys. Chem. C, 2017, 12, 2211. 63 Z. Yang, Z. Mo and X. Niu, J. Hazard. Mater., 2015, 180, 401. 64 Z. Yang, Z. Mo and X. Niu, Sep. Sci. Technol., 2015, 50, 99. 65 S. Li, Y. Shen and D. Liu, Sci. Adv. Mater., 2015, 7, 756.

66 E. Otgonjargal, Y. S. Kim, S. M. Park, K. Baek and J. S. Yang, Sep. Sci. Technol., 2012, 47, 2192.

67 B. Hudcová, V. Veselská, J. Filip, S. Číhalová and M. Komárek, Chemosphere, 2017, 168, 539.

68 L. Huang, J. Wang, Y. Gao, Y. Qiao, Q. Zheng, Z. Guo, Y. Zhao, D. O'Hare and Q. Wang, J. Mater. Chem. A, 2014, 2, 18454 .

69 Q. Wang, H. H. Tay, Z. Zhong, J. Luo and A. Borgna, Energy Environ. Sci., 2012, 5, 7526.

70 Z. Zhang, J. Wang, L. Huang, Y. Gao, A. Umar, Z. Huang and Q. Wang, Sci. Adv. Mater., 2014, 6, 1154.

71 J. Wang, W. Bao, A. Umar, Q. Wang, D. O'Hare and Y. Wan, J. Biomed. Nanotechnol., 2016, 12, 922.

72 P. Benito, I. Guinea, F. M. Labajos and V. Rives, J. Solid State Chem., 2008, 181, 987.

73 W. F. Lee and Y. C. Chen, Eur. Polym. J., 2006, 42, 1634.

74 B. Zapata, P. Bosch, G. Fetter, M. A. Valenzuela, J. Navarrete and V. H. Lara, Int. J. Inorg. Mater., 2001, 3, 23.

75 Y. W. You, H. T. Zhao and G. F. Vange, Environ. Technol., 2000, 22, 6804.

76 L. Yang, Z. Shahrivari, P. K. Liu, M. Sahimi and T. T. Tsotsis, Ind. Eng. Chem. Res., 2005, 44, 6804. 
77 M. Chetia, R. L. Goswamee, S. Banerjee, S. Chatterjee, L. Singh, R. B. Srivastava and H. P. Sarma, Clean Technol. Environ., 2012, 14, 21.

78 Y. T. Liu, M. K. Wang, T. Y. Chen, P. N. Chiang, P. M. Huang and J. F. Lee, Environ. Sci. Technol., 2006, 40, 7784.

79 Y. T. Liu, T. Y. Chen, M. K. Wang, P. M. Huang, P. N. Chiang and J. F. Lee, Appl. Clay Sci., 2010, 48, 485.

80 K. Grover, S. Komarneni and H. Katsuki, Water Res., 2009, 43, 3884.

81 K. Grover, S. Komarneni and H. Katsuki, Appl. Clay Sci., 2010, 48, 631.

82 Q. Guo and J. Tian, Chem. Eng. J., 2013, 231, 121.

83 Y. Guo, Z. Zhu, Y. Qiu and J. Zhao, J. Hazard. Mater., 2012, 239-240, 279.

84 E. Deschamps, V. S. T. Ciminelli and W. H. Holl, Water Res., 2005, 39, 5212.

85 S. Bagherifam, S. Komarneni, A. Lakzian, A. Fotovat, R. Khorasani, W. Huang, J. Ma and Y. Wang, Appl. Clay Sci., 2014, 95, 119.

86 H. Lu, Z. Zhu, H. Zhang, J. Zhu and Y. Qiu, Chem. Eng. J., 2015, 276, 365.

87 P. P. Huang, C. Y. Cao, F. Wei, Y. B. Sun and W. G. Song, RSC Adv., 2015, 5, 10412.

88 H. Lu, Z. Zhu, H. Zhang and Y. Qiu, Water, Air, Soil Pollut., 2016, 227, 1.

89 L. Ma, S. M. Islam, H. Liu, J. Zhao, G. Sun, H. Li and M. G. Kanatzidis, Chem. Mater., 2017, 29, 3274.

90 L. Yang, M. Dadwhal, Z. Shahrivari, M. Ostwal, P. K. Liu, M. Sahimi and T. T. Tsotsis, Ind. Eng. Chem. Res., 2006, 45, 4742 .

91 S. L. Wang, C. H. Liu, M. K. Wang, Y. H. Chuang and P. N. Chiang, Appl. Clay Sci., 2009, 43, 79.
92 Y. Cao, Q. Guo, Z. Shu, Y. Zhuang, Z. Yu, W. Guo, C. Zhang, M. Zhu and T. Ren, Appl. Clay Sci., 2016, 126, 313.

93 Q. Guo, Y. Cao, Y. Zhuang, Y. Yang, M. Wang and Y. Wang, Appl. Geochem., 2017, 77, 206.

94 L. Zhang, L. Li, X. Sun, P. Liu, D. Yang and X. Zhao, Materials, 2016, 9, 927.

95 M. Wang, J. Lian and X. Zhou, Sci. Adv. Mater., 2017, 9, 602.

96 H. N. Nhat Ha, N. T. Kim Phuong, T. Boi An, N. T. Mai Tho, T. Ngoc Thang, B. Quang Minh and C. Van Du, J. Environ. Sci. Health, Part A: Toxic/Hazard. Subst. Environ. Eng., 2016, 51, 403.

97 P. Z. Ray and H. J. Shipley, RSC Adv., 2015, 5, 29885.

98 S. Lata and S. R. Samadder, J. Environ. Manage., 2016, 166, 387.

99 S.-M. Jessica, J. B. Kevin and A. E. Smith, J. Am. Water Resour. Assoc., 2006, 42, 1237.

100 M. Pigna, J. J. Dynes, A. Violante, A. Sommella and A. G. Caporale, Environ. Eng. Sci., 2016, 33, 98.

101 L. M. Parker, N. B. Milestone and R. H. Newman, Ind. Eng. Chem. Res., 1995, 34, 1196.

102 Y. W. You, G. F. Vance and H. T. Zhao, Appl. Clay Sci., 2001, 20, 13.

103 R. L. Goswamee, P. Sengupta, K. G. Bhattacharyya and D. K. Dutta, Appl. Clay Sci., 1998, 13, 21.

104 A. G. Caporale, M. Pigna, J. J. Dynes, V. Cozzolino, J. Zhu and A. Violante, J. Hazard. Mater., 2011, 198, 291.

105 A. Violante and M. Pigna, Soil Sci. Soc. Am. J., 2002, 66, 1788.

106 A. Violante, M. Pigna, S. Del Gaudio, M. Ricciardella and D. Banerjee, Environ. Sci. Technol., 2007, 41, 8275.

107 S. Goldberg and C. T. Johnston, J. Colloid Interface Sci., 2001, 234, 204.

108 C. Ardau, F. Frau and P. Lattanzi, Appl. Clay Sci., 2013, 80, 1. 